\title{
Syntheses of Morphine and Codeine (1992 - 2002): Templates for Exploration of Synthetic Tools
}

\author{
L. M. Mascavage\#, M. L. Wilson and D. R. Dalton*
}

Department of Chemistry (016-00), Beury Hall, 13th and Norris Streets, Temple University, Philadelphia, PA 19122, USA and Department of Chemistry, Arcadia University, Glenside, PA, 19038, USA

\begin{abstract}
Morphine (1) and its O-methylated analogue codeine (2), analgesic alkaloids of the opium poppy (Papaver Somniferium), have been targets of organic chemists engaged in synthetic activities for at least half a century. The "first" (Gates) and "most efficient" (Rice) syntheses of morphine (1) and codeine (2) are well known and have been reviewed and analyzed extensively numerous times. However, syntheses of the same two alkaloids that have been reported since 1992 and which have been used as devices to advance the art of organic synthesis are not as widely recognized and they have not been as thoroughly reviewed. Here they are analyzed in the spirit of the use of these two compounds as templates. Further, since both racemic and enantiospecific syntheses are important and since all eight (8) approaches (since 1992) are sufficiently different so as to warrant more tha $\mathrm{n}$ superficial examination, they are all considered.
\end{abstract}

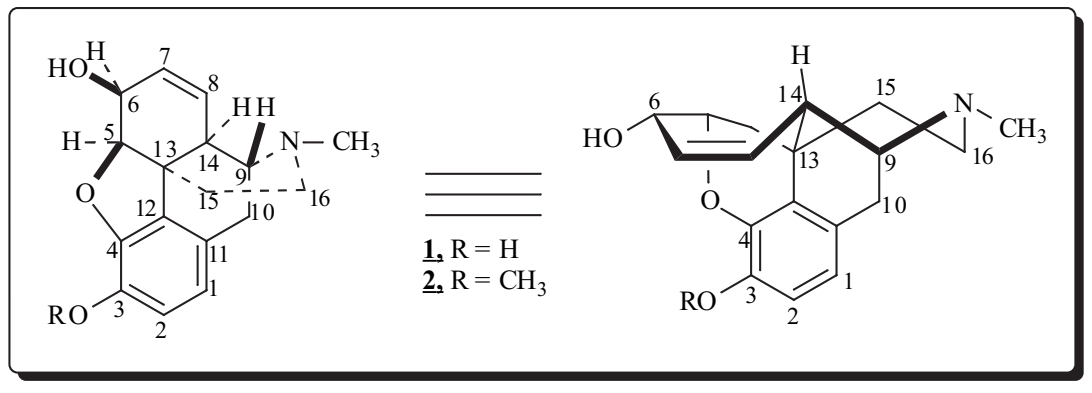

It is nearly two hundred years since the initial report (1806) of the isolation of morphine $(1, \mathrm{R}=\mathrm{H})$ from the unripe seed pods of the opium poppy, Papever somniferum, by Friedrich Wihelm Adam Setürner [1], seventy five years since the deduction of the correct molecular structure by John Mason Gulland and Sir Robert Robinson [2] and fifty years since the first synthesis (and structure proof) by Marshall Gates and Gilg Tschudi [3]. Subsequently, numerous partial and full syntheses of these alkaloids have been attempted (with varying degrees of success) and reports have been produced and review articles generated [4].

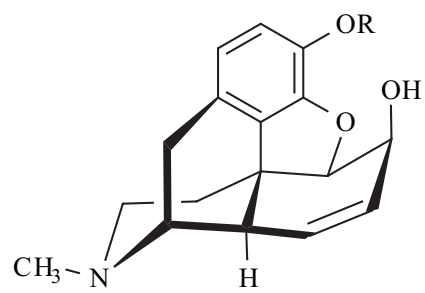<smiles>CN1CCC23CC1c1ccc(O)c4c1C2C=CC(O)C3O4</smiles><smiles>CN1CC2Cc3ccc(O)c(O)c3C(c3ccccc3)C2C1</smiles>

Fig. (1). Representations of Morphine (1), $\mathrm{R}=\mathrm{H}$, and Codeine (2), $\mathrm{R}=\mathrm{CH}_{3}$.

It is now widely recognized that it is unlikely that a purely synthetic process will be able to compete with either

*Address correspondence to this author at the Department of Chemistry (016-00), Beury Hall, 13th and Norris Streets, Temple University, Philadelphia, PA, 19122; USA; Tel: 215-204-7138 (office), 215-204-7146 (laboratory); Fax: 215-204-1532; E-mail: david.dalton@temple.edu

${ }^{\#}$ LMM is Associate Professor of Chemistry at Arcadia University. the ubiquitous standard opium poppy or with cultivars that might be subsequently generated through genetic manipulations so as to maximize production of these or related bases. Therefore, to the extent that morphine (1) and codeine (2) remain synthetic targets, it is now also clear that the syntheses must be directed not only to the bases themselves but in such a way as to be able to produce relatives (e.g., the enantiomer, diastereomers, products of "substitution" that cannot be easily made by subsequent manipulation of the natural materials, etc.) for testing purposes and to demonstrate the prowess of synthetic organic chemistry.

In the decade 1992 - 2002, eight syntheses of (1) and (2) were reported. Two of the syntheses resulted in racemic material while six can be considered "asymmetric syntheses". All eight are considered here and as already noted, some of the material to be discussed here has been 
included in other reviews and some of the striking features of those syntheses commented upon. Their value is not diminished by recapitulation and their reemphasis may serve to spark the imagination!

\section{2 : MARCUS A. TIUS AND MICHAEL A. KERR} [5]

The synthesis described is directed toward the production of isomers of thebainone (vide infra. 13) which had been converted to morphine (1) by Gates and Tschudi [1]. The work of Tius and Kerr begins with the thesis that disconnection of "aryl or arylalkyl C-C bonds (could be) strategic(ally) viable" and it is certainly true that this insightful suggestion presaged the development of many of the current catalytic methods for just such transformations [6].

The work itself began, following precedent, with the aldol condensation between 2-hydroxy-3-methoxybenzaldehyde ( $o$-vanillin) and nitromethane to produce the corresponding $\omega$-nitrostyrene and reduction of the carboncarbon double bond of the latter with sodium borohydride in methanolic tetrahydrofuran (THF) to produce a nitroalkyl phenol which, with ethyl vinyl ether in the presence of pyridinium $p$-toluenesulfonate, was protected as the ethoxyethyl ether (3) (65\% for the three steps); Fig. (2).

With the phenol protected, and without subsequent isolation of intermediate steps, reduction of the nitro group could be effected with lithium aluminum hydride in THF, the resulting amine protected as the carbamate with methyl chloroformate and the ethoxyethyl protecting the phenol removed with methanolic pyridinium $p$-toluenesulfonate (69\% for the three steps). Then, in dimethylformamide (DMF), the phenol was oxidized with oxygen in the presence of a $0.1 \mathrm{M}$ quantity of N,N-bis(salicylidene) ethylenediaminocobalt (II) (salcomine) to the corresponding quinone (4) in 78\% yield (or 35\% overall from $o$-vanillin); Fig. (3).

The classical Diels-Alder ring forming process was utilized next to generate what is destined to become the B ring of the alkaloid system (Fig. 4). Thus, the commercially available mono-ethylene ketal of 1,4-cyclohexanedione in THF underwent a Grignard reaction with commercially available vinylmagnesium bromide ( $1 \mathrm{M}$ in THF) to produce the corresponding allylic alcohol (87\%); the latter was subsequently induced to lose water (in benzene solution) in the presence of $5 \AA$ molecular sieves and $p$-toluenesulfonic

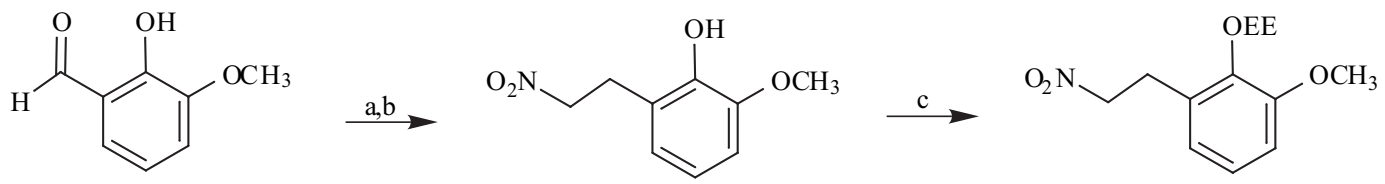

(3)

Fig (2).

(a) $\mathrm{CH}_{3} \mathrm{NO}_{2}, \mathrm{NH}_{4} \mathrm{OAc}, \mathrm{HOAc}$; (b) $\mathrm{NaBH}_{4}, \mathrm{MeOH} / \mathrm{THF}$; (c) $\mathrm{CH}_{2}=\mathrm{CHOCH}_{2} \mathrm{CH}_{3}, \mathrm{CH}_{2} \mathrm{Cl}_{2}$, PyOTs.

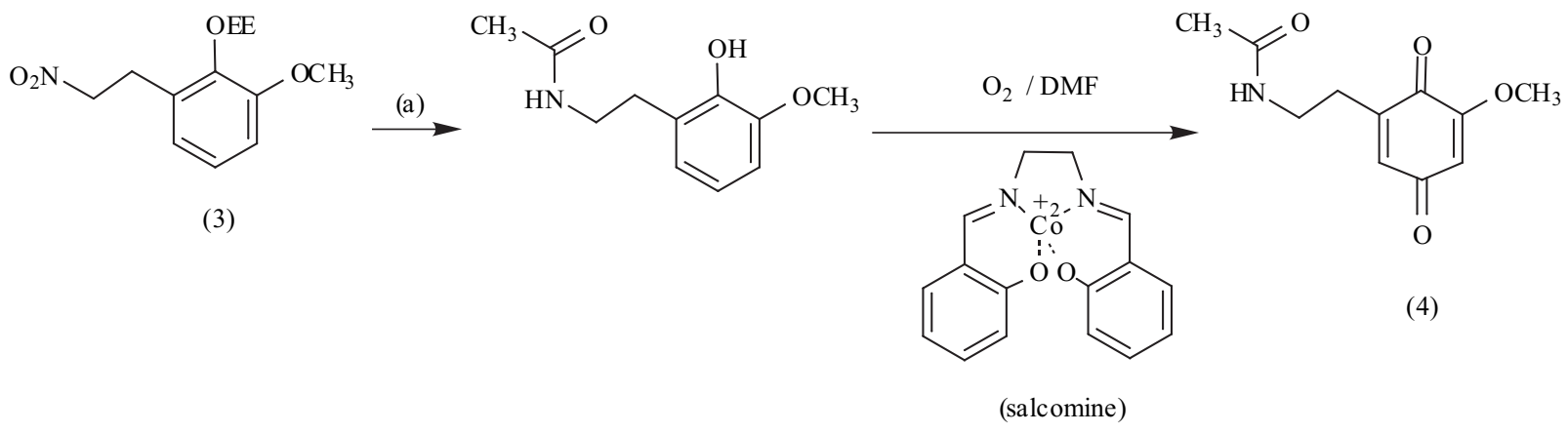

Fig. (3).

(a) $\mathrm{LiAlH}_{4}$ in THF; $\mathrm{ClCOCH}_{3}, \mathrm{CH}_{2} \mathrm{Cl}_{2}, I$-PrNEt 2 ; PyOTs, $\mathrm{CH}_{3} \mathrm{OH}$.<smiles>C=CC1=CCC2(CC1)OCCO2</smiles>

(5)<smiles>COC1=CC(=O)C=C(CCNC(C)=O)C1=O</smiles>

(4)<smiles>COC1=CC(=O)[C@H]2CC=C3CCC4(CC3C2(I)C(=O)C1=O)OCCO4</smiles>

(6)

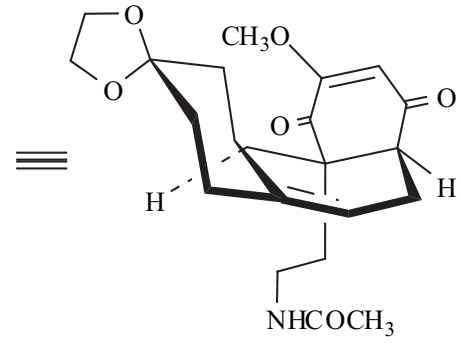

$\mathrm{NHCOCH}_{3}$

Fig. (4). The Diels-Alder Reaction. 
<smiles>COC1=CC(=O)[C@H]2CC=C3CCC4(C[C@H]3[C@@H]2[C@@H]4CCNC(C)=O)C(=O)C1OC</smiles>

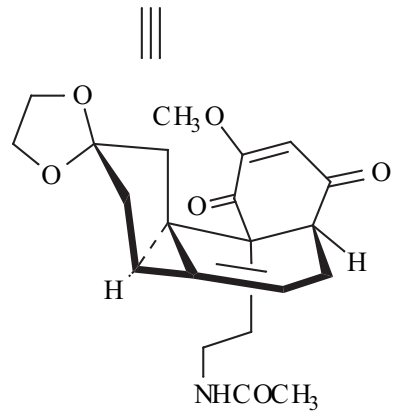

(6)

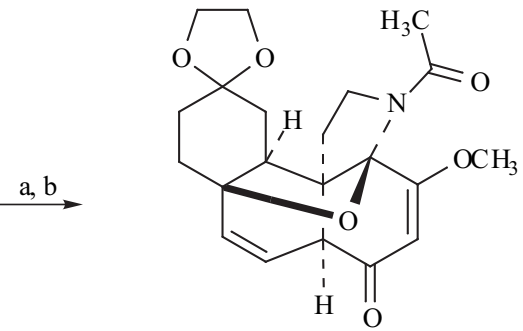<smiles>C#C</smiles>

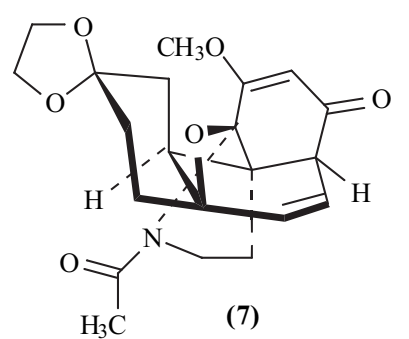

Fig. (5).

(a) $\mathrm{C}_{6} \mathrm{H}_{5} \mathrm{SeCl}, \mathrm{CH}_{3} \mathrm{OH}, 0{ }^{\circ} \mathrm{C}$; (b) THF, $\mathrm{H}_{2} \mathrm{O}_{2}(30 \%)$.

acid to produce the corresponding diene (5) (34\%), written here as the $Z$-isomer. The Diels-Alder reaction between 4 and 5 at $100{ }^{\circ} \mathrm{C}$ in toluene yielded (86\%) a single product (6).

When the dienone (6) was treated with phenylselenium chloride in methanol at $0{ }^{\circ} \mathrm{C}$ [Fig. (5)] an "unusual ... (and un)anticipated" tandem selenocyclization involving the carbamate occurred and oxidative elimination of the selenium produced the alkene (7) $(80 \%)$.

The structure of the ketal (7) was confirmed by single crystal $\mathrm{x}$-ray diffraction analysis. Then, hydrolysis of the ketal with aqueous hydrogen chloride yielded the corresponding ketone and generation of the potassium enol of the latter with potassium bis(trimethylsilyl)amide in THF at $-78^{\circ} \mathrm{C}$ followed by oxaziridine oxidation produced the acyloin (8) in $70-88 \%$ yield as shown in Fig. (6).

Catalytic ( $10 \% \mathrm{Pd}$ on C) hydrogenation of the nonconjugated carbon-carbon double bond in $\mathbf{8}$, followed by Swern type oxidation (dimethyl sulfoxide in $\mathrm{CH}_{2} \mathrm{Cl}_{2}$ with trifluoroacetic anhydride) of the dihydroacyloin generated a (presumed) diketone (written here as the enolic tautomer). Without purification, the ketoenol was treated (in dichloro-
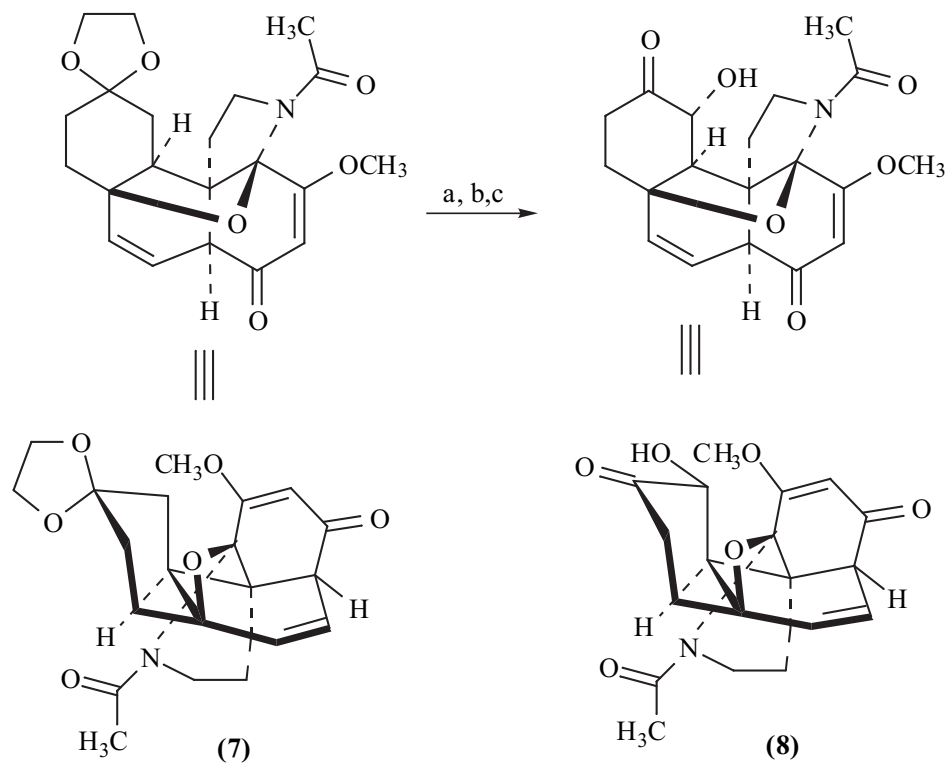

Fig. (6).

(a) aq $\mathrm{HCl}$, THF; (b) $\mathrm{K}^{+}\left[\mathrm{N}(\mathrm{TMS})_{2}\right]^{-}$, THF, $-78^{\circ} \mathrm{C}$; (c) THF, 3-phenyl-2-(phenylsulfonyl)oxaziridine. 


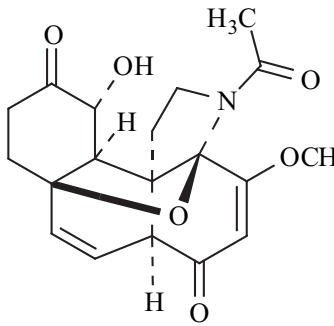

(8)

\section{(a)}

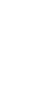

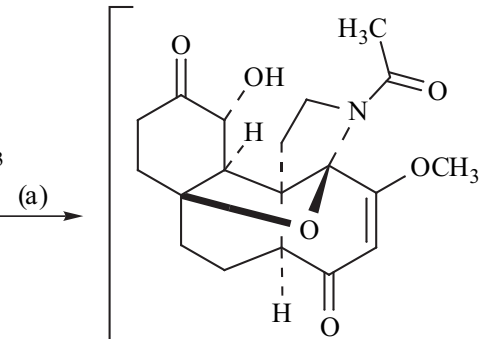

(b)

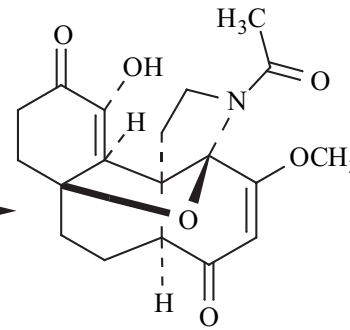

(c)<smiles></smiles>

(d)

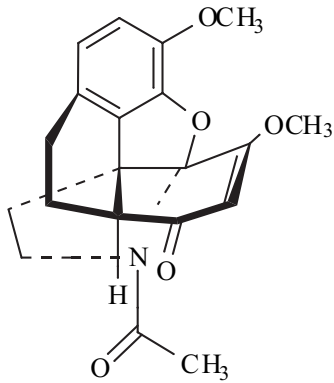

(9)

Fig. (7).

(a) $\mathrm{H}_{2}(10 \% \mathrm{Pd} / \mathrm{C})$ in THF; (b) $\left(\mathrm{CH}_{3}\right)_{2} \mathrm{SO},\left(\mathrm{CF}_{3} \mathrm{CO}\right)_{2} \mathrm{O}$; (c) $\mathrm{BF}_{3} \cdot \mathrm{O}(\mathrm{Et})_{2}$; (d) $\mathrm{K}_{2} \mathrm{CO}_{3}$, acetone, $\mathrm{CH}_{3} \mathrm{I}$.

methane at $-30^{\circ} \mathrm{C}$ ) with boron trifluoride etherate to effect aromatization and this material (with the dihydrofuran ring in place, a "fortunate turn of events") was directly converted to the methyl ether 9 on treatment (in acetone) with anhydrous potassium carbonate and methyl iodide. The overall yield from 8 was $56 \%$; Fig. (7).

Treatment of 9 with phenylselenium chloride in ethyl acetate followed by immediate oxidation of the crude selenide with hydrogen peroxide produced an enone in $70 \%$<smiles>COC1=CC(=O)C2CCc3ccc(OC)c4c3C23N(C(C)=O)CC143</smiles>

(a)

(9)<smiles>COC1=C[C@@H](O)C2=CCc3ccc(OC)c4c3C23CC1N3C4(C)C</smiles><smiles>[GeH2]=[Te]</smiles>

Fig. (8). yield and reduction with sodium borohydride in methanol produced the corresponding alcohol which was not purified but rather dissolved in dry THF and treated with a ten fold excess of methyllithium at $0{ }^{\circ} \mathrm{C}$. The presumed secondary amine was, again without purification, dissolved in acetonitrile and treated with an excess of aqueous formaldehyde followed by sodium cyanoborohydride for 15 min. The yield of the resulting N-methylamine (10), over the three steps of borohydride reduction of the enone, and<smiles></smiles><smiles></smiles>

(10)

(a) $\mathrm{C}_{6} \mathrm{H}_{5} \mathrm{SeCl}$, EtOAc, $\mathrm{H}_{2} \mathrm{O}_{2}$; (b) $\mathrm{NaBH}_{4}, \mathrm{CH}_{3} \mathrm{OH}$; (c) $\mathrm{CH}_{3} \mathrm{Li}$, THF / then $\mathrm{CH}_{3} \mathrm{CN}, \mathrm{CH}_{2} \mathrm{O}, \mathrm{NaCNBH}_{3}$. 
<smiles>COC1=C[C@@H](O)C2=CCc3ccc(OC)c4c3C2(I)C1(I)CN4C</smiles>

(10)
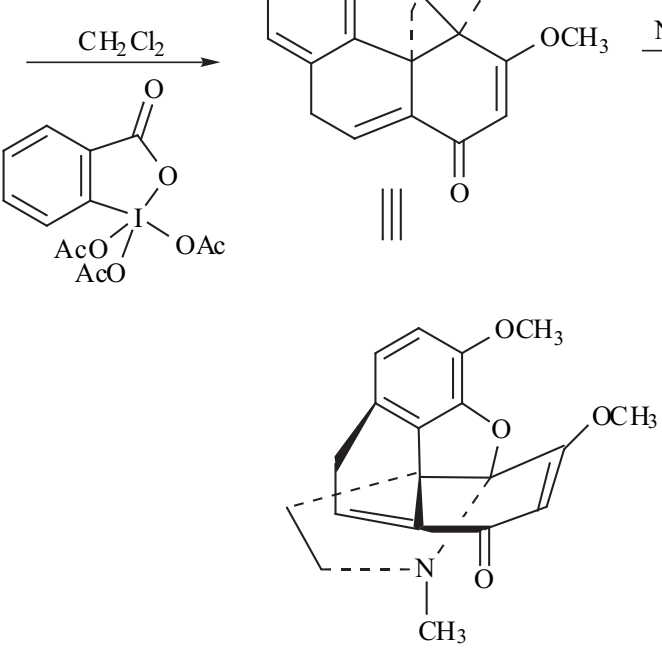

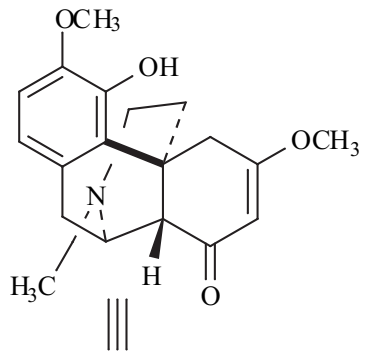<smiles>COc1ccc2c(c1O)C13CCN(C)[C@H](C2)C1(C)C[C@H](OC)C3=O</smiles>

(11)

Fig. (9). Morphinane formation.

decarbamylation and reductive methylation at nitrogen was 54\%; Fig. (8).

Periodane (Dess-Martin Reagent [1,1,1-triacetoxy-1,1dihydro-1,2-benziodoxol-3(1H)-one]) oxidation of the allylic alcohol (10) in methylene chloride produced the corresponding ketone (74\%) which, on standing for $24 \mathrm{hr}$ in ethanolic aqueous ammonium chloride in the presence of zinc dust underwent the remarkable transformation to morphinane (11) in a reported 73\% yield; Fig. (9).

Given the incorrect stereochemistry at the ring juncture $\alpha$ - to the carbonyl (i.e., the proton is cis- to the aromatic ring) it was clear that inversion was necessary. The inversion was accomplished by carbonyl transposition (Fig. (10). Thus, when the morphinane (11) was dissolved in dry THF and treated with diisobutylaluminum hydride (DIBAL-H) the carbonyl group was reduced to the corresponding alcohol. The latter underwent elimination when the enol ether was hydrolyzed with dilute acid and the ketone (12) was produced. Epimerization to racemic thebainone (13) was completed by treatment of $\mathbf{1 2}$ with acetic acid followed by basification with dilute ammonium hydroxide.

Thebainone (13) has, classically, been converted to codeine (2) and to morphine (1) via dihydrothebainone again and again since the original process by Marshall Gates and Gilg Tschudi was reported [3].

The conversion of thebainone (13) to codeine (2) and thence to morphine (1) was not reported by Tius and Kerr, but it is included here to complete the picture of the synthetic work involved.

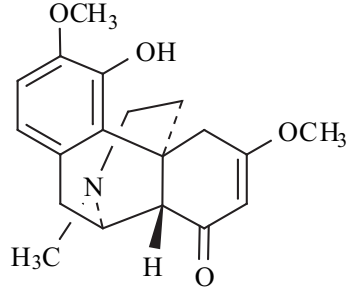

||

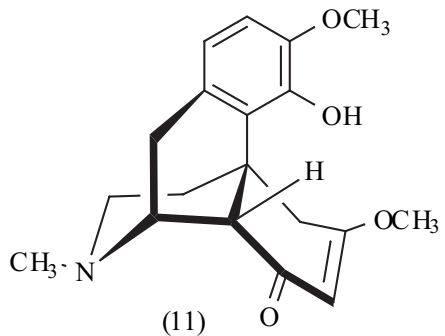

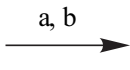<smiles>COc1ccc2c(c1O)C13CCCC1(CC(=O)C=C2)[C@H]3C</smiles>

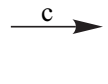

(12)

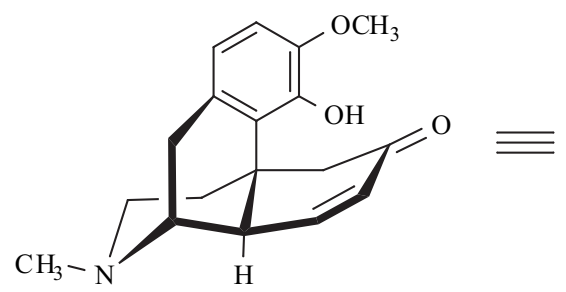

$\mathrm{CH}_{3}$

Fig. (10). Formation of thebainone (13).

(a) $\left[\left(\mathrm{CH}_{3}\right)_{2} \mathrm{CHCH}_{2}\right]_{2} \mathrm{AlH}$, THF; (b) $3 \% \mathrm{HCl}$; (c) $\mathrm{CH}_{3} \mathrm{CO}_{2} \mathrm{H}$ followed by $\mathrm{NH}_{4} \mathrm{OH}$. 


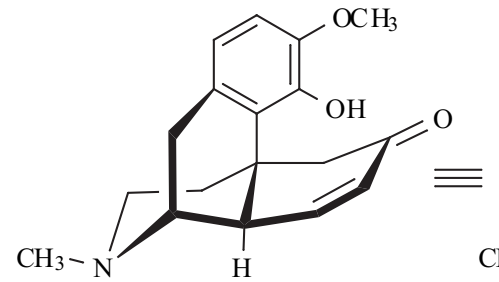

$\mathrm{H}$<smiles>COc1ccc2c(c1O)C1(C)CC(=O)C=CC1CNC2C</smiles>

(13)

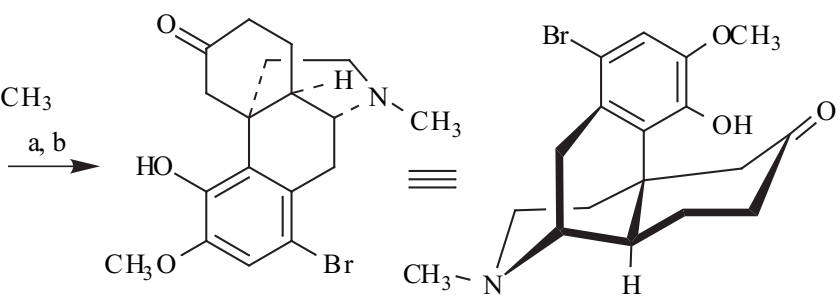

(14)

Fig. (11). Thebainone to 1-bromodihydrothebainone [3].

(a) $\mathrm{Br}_{2}$ in $\mathrm{CH}_{3} \mathrm{CO}_{2} \mathrm{H}$; (b) Adams Catalyst $\left(\mathrm{PtO}_{2}\right), \mathrm{H}_{2}$, ethanol.

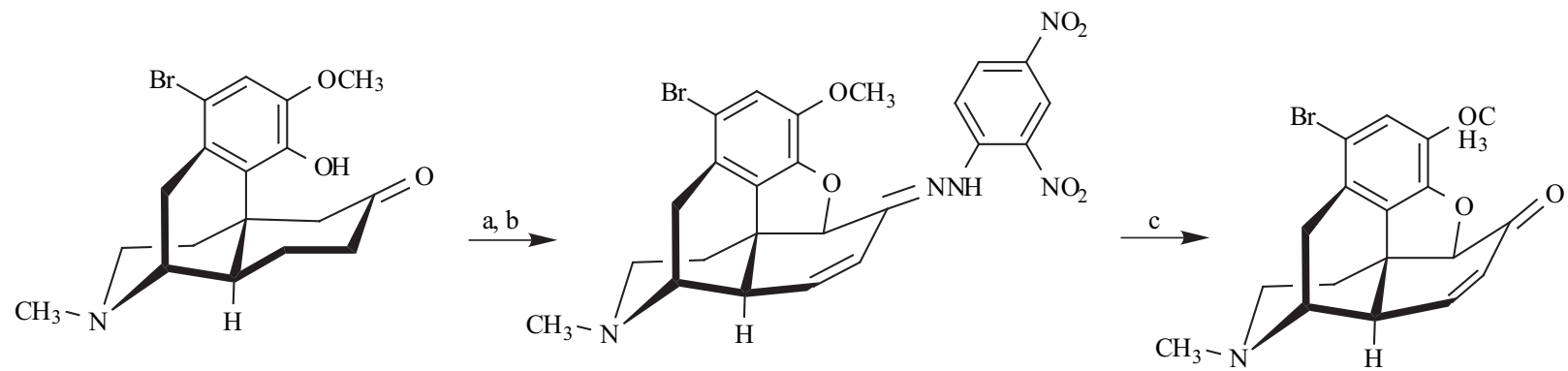

(14)

Fig. (12). 1-Bromodihydrothebainone to 1-bromocodeinone [3].

(a) $\mathrm{Br}_{2}$ in $\mathrm{CH}_{3} \mathrm{CO}_{2} \mathrm{H}$; (b) 2,4-dinitrophenylhydrazine, $\mathrm{NaOAc}$; (c) acetone, $\mathrm{HCl}$.

Following Gates and Tschudi [3], bromination of thebainone (13) in acetic acid results in the formation of 1bromothebainone which can be hydrogenated over platinum catalyst in ethanol to 1-bromodihydrothebainone (14); Fig. (11). When this bromophenol as the hydrobromide dihydrate, in glacial acetic acid was treated with bromine in glacial acetic acid and then with 2,4-dinitrophenylhydrazine followed by anhydrous sodium acetate, a $26 \%$ yield of 1 bromocodeinone-2,4-dinitrophenylhydrazone was obtained; Fig. (12). The protecting group was removed in $27 \%$ yield by refluxing the base in acetone containing $12 \mathrm{~N}$ hydrochloric acid.

Finally, codeine (2) was obtained from the 1bromocodeinone by reduction with lithium aluminum hydride $\left(\mathrm{LiAlH}_{4}\right)$ in THF in about $30 \%$ yield and demethylation to morphine (1) itself effected (in 34\% yield) by reaction with pyridinium hydrochloride - the procedure pioneered by Henry Rapoport, Calvin H. Lovell and Bert M. Tolbert [7].

\section{2 : KATHLYN A. PARKER AND DEMOSTHENES FOKAS [8]}

Following a significant exploration of the possibility of utilizing tandem radical cyclizations in ring construction $[9,10]$ Parker and Fokas set out to effect a short (11 steps from commercially available materials) convergent synthesis of racemic morphine (1).

Their synthesis begins with the conversion of 2-(3methoxyphenyl)ethyl amine by Birch reduction, tosylation and hydrolysis to the corresponding cyclohexenone and $\mathrm{N}$ methylation to the $\mathrm{N}$-methyltosylamide (15) in $76 \%$ yield for the three steps; Fig. (13).

Reduction of the carbonyl of ketone (15) with sodium borohydride in the presence of cerium trichloride at zero degrees followed by epoxidation with meta-chloroperbenzoic acid placed the epoxide oxygen and the hydroxyl on the same face of the cyclohexane ring. Then opening of the epoxide with titanium isopropoxide in benzene produced the corresponding cis-diol, the less hindered hydroxyl of which

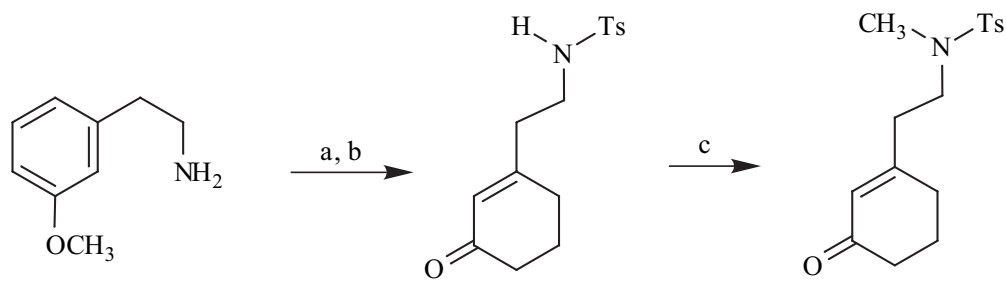

(15)

Fig. (13).

(a) $\mathrm{Li} / \mathrm{NH}_{3}(\mathrm{l}), t-\mathrm{BuOH},-68^{\circ} \mathrm{C}$; (b) $\mathrm{TsCl}, \mathrm{NEt}_{3}$, THF followed by $1 \mathrm{~N} \mathrm{HCl}$; (c) $\mathrm{CH}_{3} \mathrm{I}, \mathrm{K}_{2} \mathrm{CO}_{3}$, acetone. 
<smiles>CN([15NH])CCC1=CC(=O)CCC1</smiles>

(15)
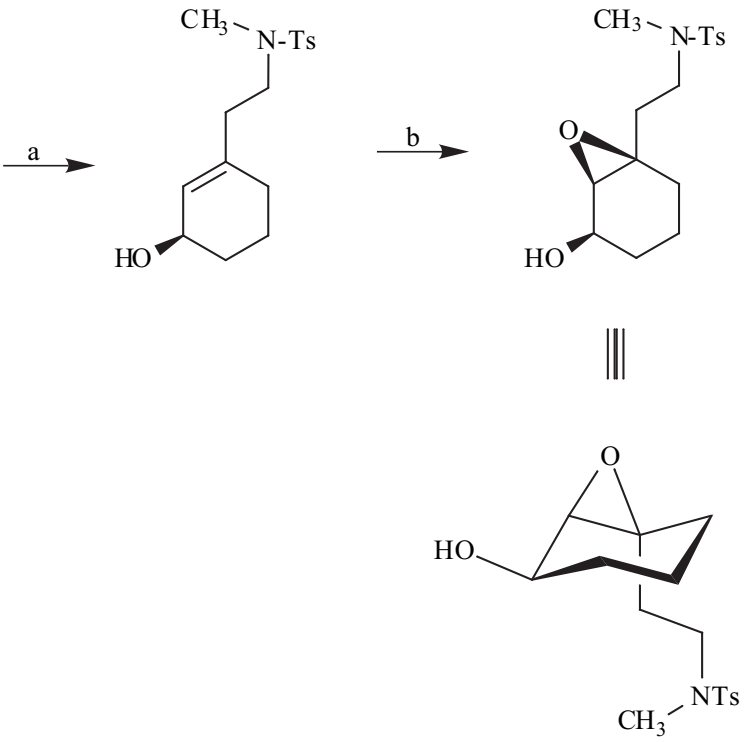

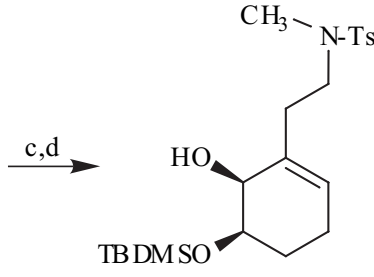

(16)

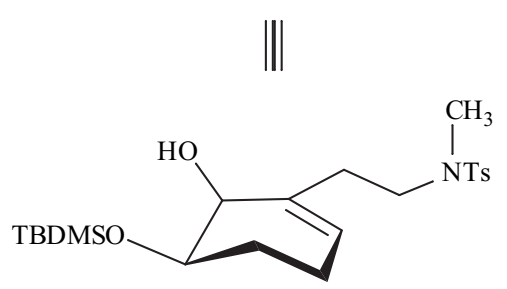

Fig. (14).

(a) $\mathrm{NaBH}_{4}, \mathrm{CeCl}_{3}$. $\mathrm{CH}_{3} \mathrm{OH}$; (b) $m$-CPBA, $\mathrm{CH}_{2} \mathrm{Cl}_{2}$; (c) Ti(OPr) ${ }_{4}, \mathrm{C}_{6} \mathrm{H}_{6}$; (d) TBDMSOTf, $i$ - $\mathrm{Pr}_{2} \mathrm{NEt}$.

was protected as the $t$-butyldimethylsilyl derivative (16) in $62 \%$ for the four steps; Fig. (14).

Then, when the alcohol (16) was coupled in a Mitsunobu reaction, using diethylazodicarboxylate (DEAD) and tri- $n$ butylphosphine in THF at $0{ }^{\circ} \mathrm{C}$ with the phenol derived from bromination of 3-hydroxy-4-methoxybenzaldehyde (isovanillin) followed by reaction of the bromoaldehyde with diethyl[(phenylthio)methyl]phosphonate and the protecting silyl group removed with $10 \% \mathrm{HF}$ in acetonitrile $(81 \%$ for the two steps), a radical coupling substrate (17) was ready [Fig. (15)]. The coupling was effected in 35\% yield using tri- $n$-butyltin hydride $\left(\mathrm{Bu}_{3} \mathrm{SnH}\right)$, azobisisobutyronitrile (AIBN) in benzene at $130{ }^{\circ} \mathrm{C}$ for 35 hours. Then, in an "unprecedented" process [Fig. (16)], which has subsequently been widely emulated, treatment of the tosylamide 17 with lithium metal in liquid ammonia in the presence of $t$-butyl alcohol at $-78{ }^{\circ} \mathrm{C}$ resulted in detosylation and ring closure to racemic dihydroisocodeine (18) in $85 \%$ yield.

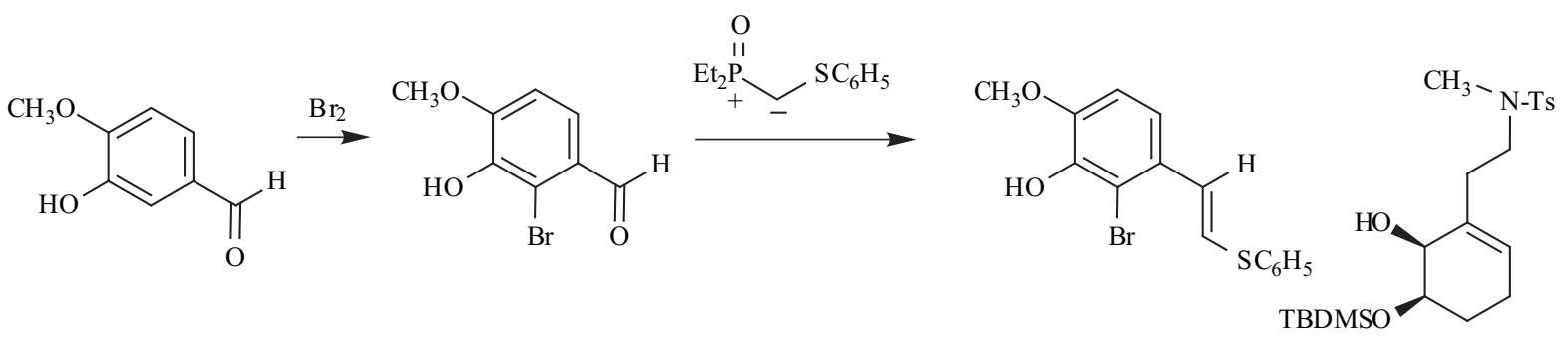

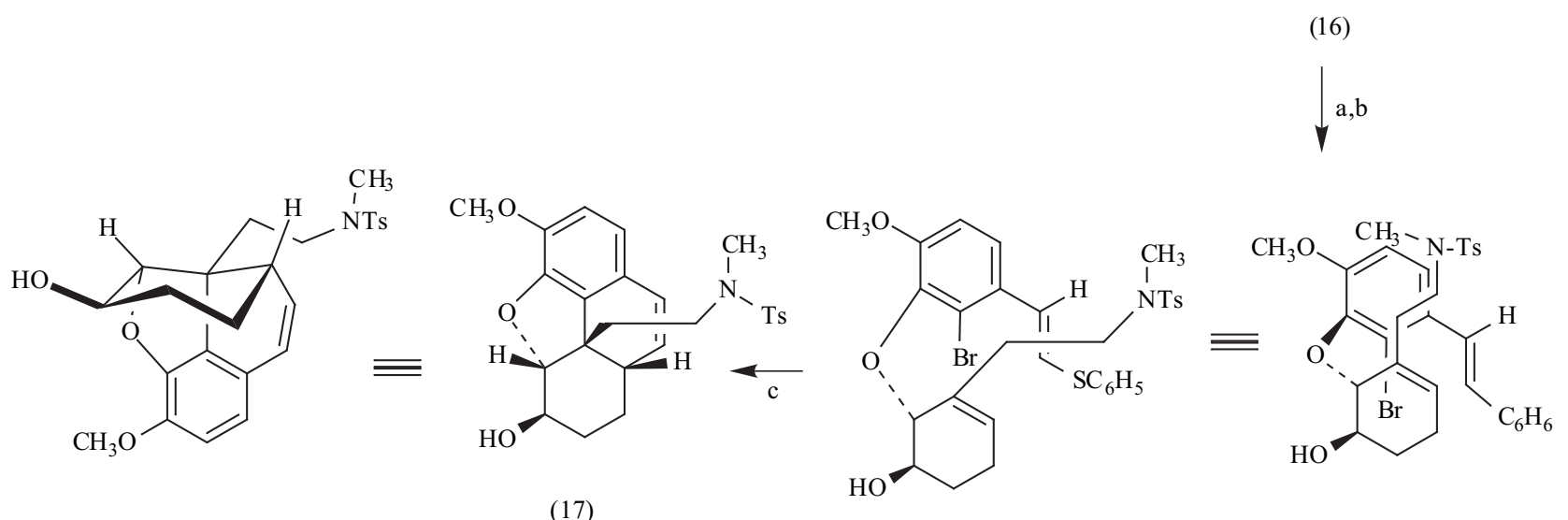

Fig. (15).

(a) $\mathrm{PBu}_{3}$, DEAD, THF, $0{ }^{\circ} \mathrm{C}$; (b) $10 \% \mathrm{HI}, \mathrm{CH}_{3} \mathrm{CN}$; (c) $\mathrm{Bu}_{3} \mathrm{SnH}, \mathrm{AIBN}, \mathrm{C}_{6} \mathrm{H}_{6}, 130{ }^{\circ} \mathrm{C}$. 


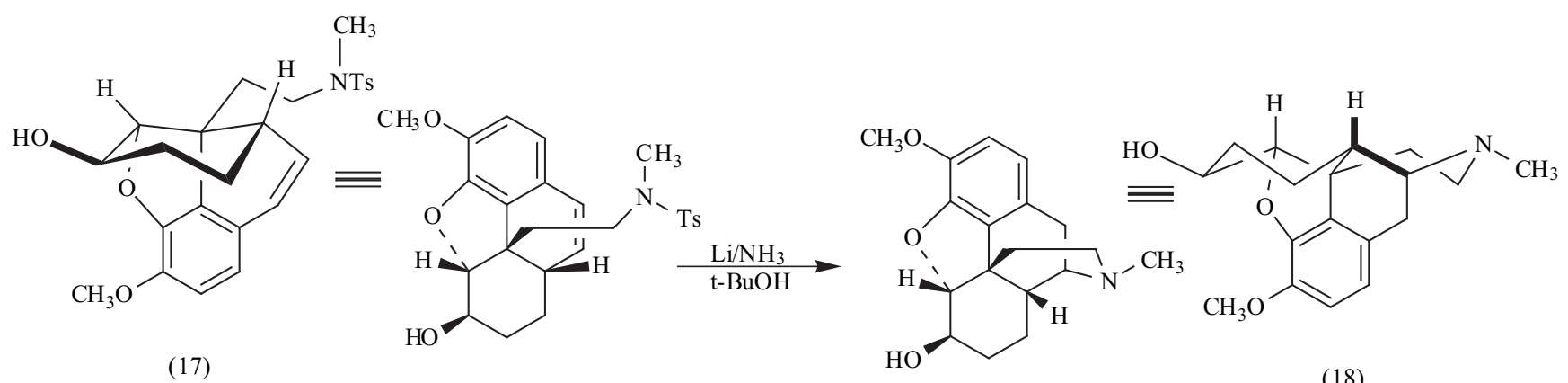

(18)

Fig. (16). The cyclization to ( \pm )-dihydroisocodeine.

Swern type oxidation (with oxalyl chloride and dimethyl sulfoxide) of the racemic dihydroisocodeine (18) produced the corresponding ketone, $( \pm)$-dihydrocodeinone (19) (in $83 \%$ yield). Dihydrocodeinone (19) had earlier been converted to codeine (2) [11]. Thus, Dwight W. Weller and Henry Rapoport found that ketalization of dihydrocodeinone (19) with trimethylorthoformate in methanol with a trace of sulfuric acid followed by toluenesulfonic acid (in chloroform) resulted in the elimination of methanol and yielded the corresponding enol ether (20) in $82 \%$ yield (for the two steps). The hydrobromide of the enol ether (prepared from the enol ether with aqueous $\mathrm{HBr}$ ) on treatment with $\mathrm{N}$ bromoacetamide in methanol produced the corresponding bromodihydrocodeine dimethyl ketal $(21)$ in $83 \%$ yield and treatment of the latter with potassium tert-butoxide at $60{ }^{\circ} \mathrm{C}$ in dimethyl sulfoxide for 7 hours resulted in an $87 \%$ yield of the ketal of codeinone itself; Fig. (17).

Hydrolysis of the ketal with dilute sulfuric acid produced codeinone, the reduction of which with lithium aluminum hydride (vide supra) to codeine (2) had already been accomplished by Gates and Tschudi [3].

\section{3: CHANG Y. HONG, NORIYUKI KADO AND LARRY E. OVERMAN [12]}

Noting that pharmacological properties are dependent upon absolute configuration as well as apparently minor changes in structure, this group reported the development of syntheses of "either enantiomer" of morphine (1) and codeine (2). The proposed strategy, eventually realized, was to utilize an intramolecular palladium catalyzed aryl halide-to-alkene coupling reaction (the Heck reaction) to forge the quaternary carbon center on a chiral substrate. The chiral substrate was an enantioenriched octahydroisoquinoline, either enantiomer of which could be prepared and which would subsequently define the other stereocenters.

The synthesis began with the preparation of 2allylcyclohex-2-ene-1-one (22) which was generated from commercially available 2-methoxybenzoic acid [13]; Fig. (18).

Then, reduction of the carbonyl group in the presence of $(R)$-oxazaborolidine with catecholborane provided the corresponding $(S)$ cyclohexanol $(93 \%,>96 \%$ ee) and

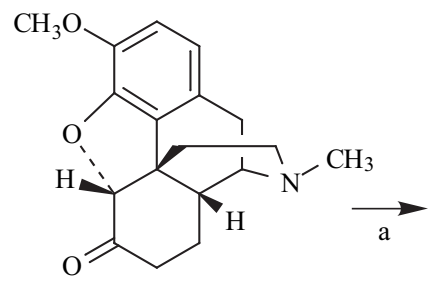

(19)

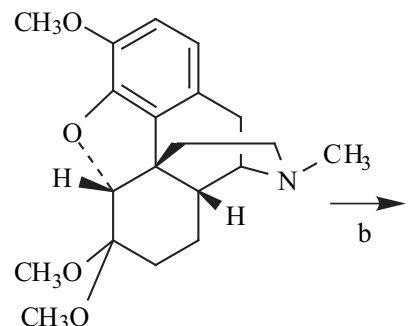

$\mathrm{CH}_{3} \mathrm{O}$

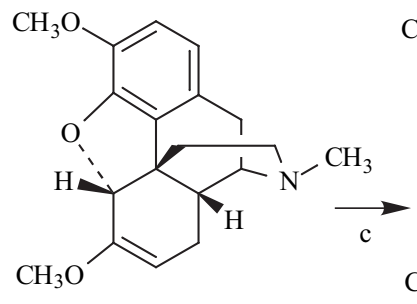

(20)<smiles>COc1ccc2c3c1O[C@@H]1C[C@@H]3[C@@H](C2)CC(Br)C1OC</smiles>

d

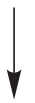

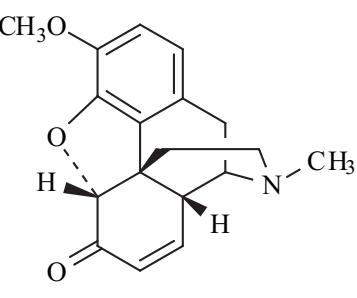

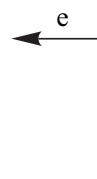

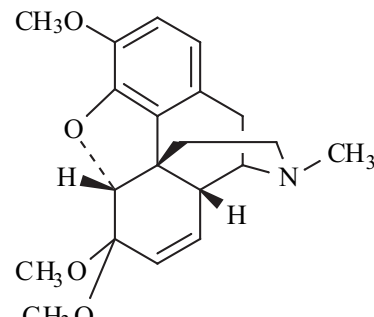

(2)

Fig. (17). The conversion of dihydrocodeinone to codeine.

(a) $\mathrm{HC}\left(\mathrm{OCH}_{3}\right)_{3}, \mathrm{CH}_{3} \mathrm{OH}, \mathrm{H}_{2} \mathrm{SO}_{4}$; (b)HOTs, $\mathrm{CHCl}_{3}$; (c) $\mathrm{CH}_{3} \mathrm{CONHBr}, \mathrm{CH}_{3} \mathrm{OH}$; (d) $\left(\mathrm{CH}_{3}\right)_{2} \mathrm{SO}, t-\mathrm{BuO}^{-}$; (e) $\mathrm{H}_{2} \mathrm{SO}_{4}$; (f) $\mathrm{LiAlH}_{4}, \mathrm{THF}$. 


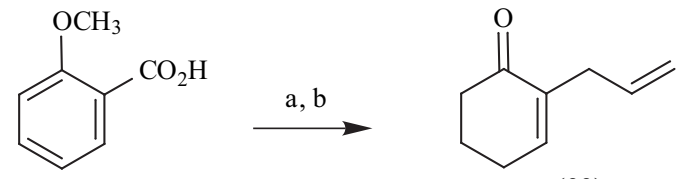

Fig. (18). Preparation of 2-allylcyclohex-2-en-1-one [13].

(a) $\mathrm{Li}, \mathrm{NH}_{3}$ (l) ; (b) $\mathrm{ClCH}_{2} \mathrm{CH}=\mathrm{CH}_{2}, \mathrm{BrCH}_{2} \mathrm{CH}_{2} \mathrm{Br}, \mathrm{HCl}_{\text {(aq) }}$ hydrolysis.<smiles>C=CCC1=CCCCC1=O</smiles>

(22)

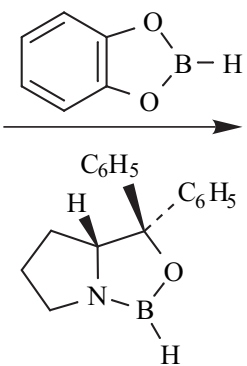

$\mathrm{H}$

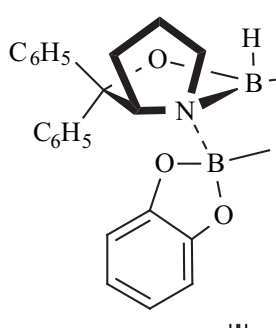

$\|$

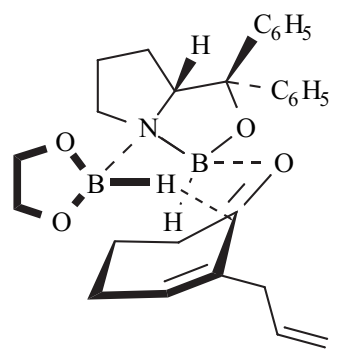

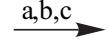<smiles>CC1(C)OCC(CC2=CCCC[C@H]2OC(=O)Nc2ccccc2)O1</smiles>

Fig. (19).

(a) $\mathrm{C}_{6} \mathrm{H}_{6}-\mathrm{N}=\mathrm{C}=\mathrm{O}$; (b) $\mathrm{OsO}_{4}, \mathrm{~N}$-methylmorpholine N-oxide; (c) $\mathrm{CH}_{3} \mathrm{COCH}_{3}, \mathrm{H}^{+}$.

condensation of that intermediate with phenyl isocyanate followed by osmium tetroxide dihydroxylation and diol protection with acetone produced the protected triol $\mathbf{2 3}$ in $68 \%$ overall yield from 22; (Fig. (19).
The allylsilane (24) was obtained from the carbamate (23) [Fig. (20)] with good stereochemical integrity by an apparent suprafacial $\mathrm{S}_{\mathrm{N}} 2$ ' displacement by the dimethyl-phenylsilyl anion generated by treatment of the allylcarbamate, in THF,<smiles>CC1(C)OC[C@H](CC2=CCCC[C@H]2OC(=O)Nc2ccccc2)O1</smiles>

(23)

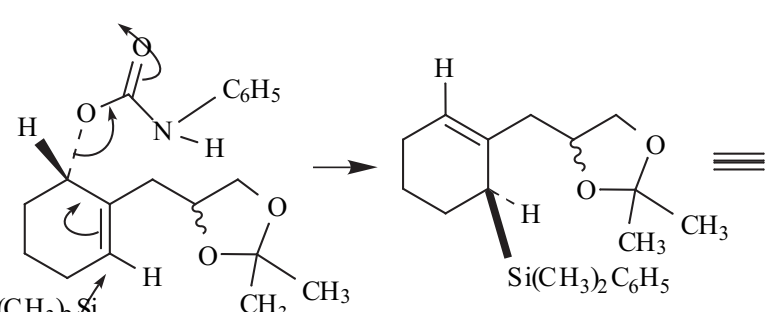
$\mathrm{C}_{6} \mathrm{H}_{5}\left(\mathrm{CH}_{3}\right)_{2}$, $\mathrm{Li}$
$\mathrm{CH}_{3} \mathrm{CH}_{3}$$$
\mathrm{Li}
$$ 
with $n$-butyl lithium (1.1 eq. at $\left.-30{ }^{\circ} \mathrm{C}\right)$ and then $\mathrm{CuI}\left[\left(\mathrm{C}_{6} \mathrm{H}_{5}\right)_{3} \mathrm{P}\right]_{2}\left(1.0\right.$ eq. at $\left.0{ }^{\circ} \mathrm{C}\right)$ and $\mathrm{C}_{6} \mathrm{H}_{5}\left(\mathrm{CH}_{3}\right)_{2} \mathrm{SiCl}(2.0$ eq. also at $\left.0{ }^{\circ} \mathrm{C}\right)$.

Subsequently, cleavage of the acetonide with methanolic $p$-toluenesulfonic acid and periodate cleavage produced a $\beta, \gamma$-unsaturated aldehyde which was immediately treated with dibenzosuberylamine (DBS- $\left.\mathrm{NH}_{2}\right)$ and sodium cyanoborohydride to produce the chiral homoallylic amine (25).

When 3-hydroxy-4-methoxybenzaldehyde (isovanillin, vide supra) was converted to its dimethylacetal and the phenolic hydroxyl protected as the methyl monomethyl ether (MOM), lithiation followed by treatment with iodine could be effected to produce the corresponding iodio derivative which, after removal of the MOM group and reprotection of the phenolic oxygen as the benzyl derivative, yielded 3benzyloxy-2-iodo-4-methoxybenzaldehyde (26) in $96 \%$ overall yield; Fig. (21). The aldehyde could be converted to its next higher homologue by treatment with dimethylsulfonium methylide to produce the corresponding epoxide which was then converted to the phenylacetaldehyde (27) by treatment with borontrifloride etherate in $84 \%$ yield.

Condensation of the aldehyde 27 with the chiral amine 25 in the presence of $\mathrm{ZnI}_{2}(5 \mathrm{~mol} \%)$ produced the corresponding, crystalline octahydroisoquinoline (28) in 82 $\%$ yield $(91 \%$ ee) and treatment of $\mathbf{2 8}$ with a catalyst formed from $\mathrm{Pd}\left(\mathrm{O}_{2} \mathrm{CF}_{3}\right)_{2}\left[\left(\mathrm{C}_{6} \mathrm{H}_{5}\right)_{3}\right]_{2}$ and 4 equivalents of 1,2,2,6,6pentamethylpiperidine in refluxing toluene consummated the Heck cyclization (forming 29) in 60\% yield; Fig. (22).

The conversion to (-) - dihydrocodeinone (19) [which can, in turn, be converted, vide supra, to codeine (2) and morphine (1)] was accomplished by (1) debenzylation of 29 with $\mathrm{BF}_{3}$-etherate to the phenol; (2) cyclization of the phenol to the furan by treatment of its camphorsulfonate salt with 3,5-dinitroperoxybenzoic acid in $\mathrm{CH}_{2} \mathrm{Cl}_{2}$ at $0{ }^{\circ} \mathrm{C}$; (3) oxidation of the remaining hydroxyl group with tetrapropylammonium perruthenate (TPAP) in the presence of N-methylmorpholine N-oxide (NMO) to the ketone; and<smiles>COc1ccc(C=O)cc1O</smiles><smiles>COc1ccc(C=O)c(I)c1OCC(C)C</smiles><smiles>COc1ccc(C2CO2)c(I)c1OCc1ccccc1</smiles><smiles>COc1ccc(CC=O)c(Br)c1Br</smiles>

(26)

Fig. (21).

(a) $\mathrm{CH}\left(\mathrm{OCH}_{3}\right)_{3}$, $\mathrm{HOTs}$; (b) $\mathrm{ClCH}_{2} \mathrm{OCH}_{3}$; (c) $n$-BuLi, $\mathrm{I}_{2}$; (d) $\mathrm{H}_{3} \mathrm{O}^{+}$; (e) $\mathrm{BnBr}$; (f) $\left.\mathrm{CH}_{2}=\mathrm{S}_{\left(\mathrm{CH}_{3}\right.}\right)_{2}$; (g) $\mathrm{BF}_{3} \bullet \mathrm{OEt}_{2}$.

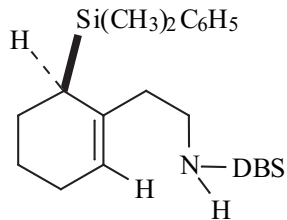

(25)<smiles>CCCCOc1c(OC)ccc(CC=O)c1I</smiles><smiles>[107Os]</smiles>
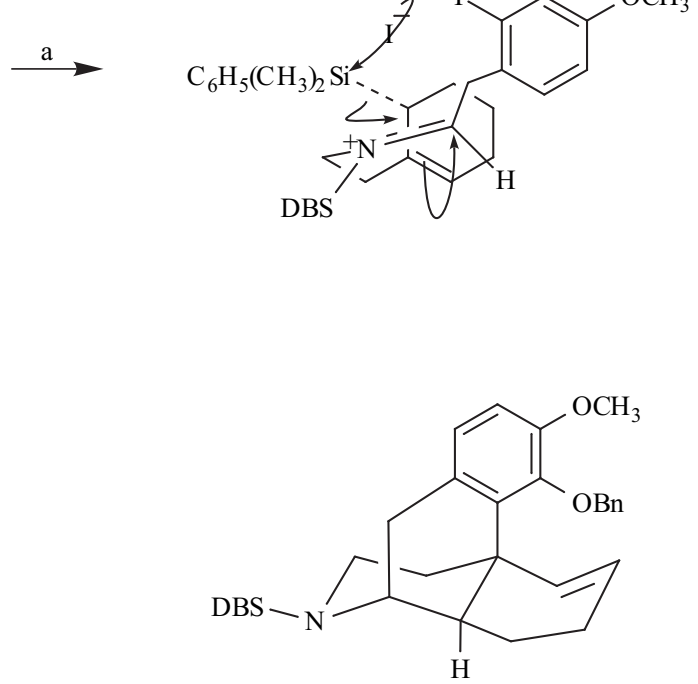

(29)

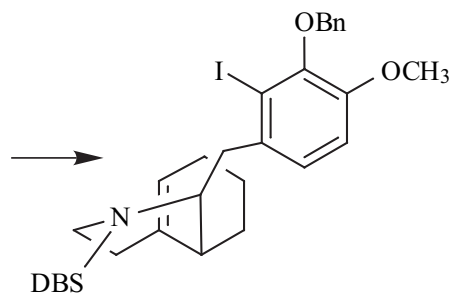

||<smiles>[R5]N1CCC2=CCCCC2[C@@H]1Cc1ccc(OC)c(OCc2ccccc2)c1I</smiles>

Fig. (22).

(a) $\mathrm{ZnI}_{2}$, ethanol; (b) $\mathrm{Pd}\left(\mathrm{O}_{2} \mathrm{CF}_{3}\right)_{2}\left[\left(\mathrm{C}_{6} \mathrm{H}_{5}\right)_{3}\right]_{2}$, 1,2,2,6,6-pentamethylpiperidine, toluene. 


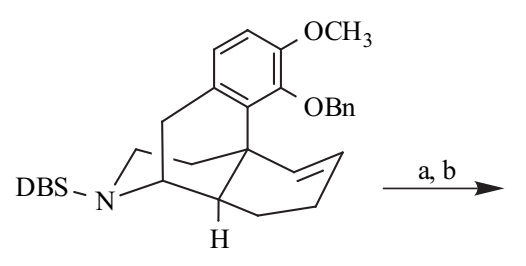

(29)

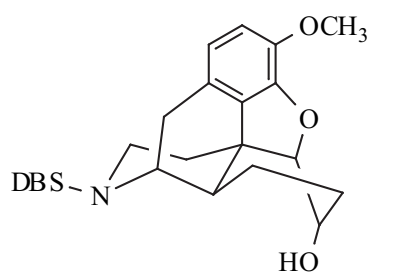

$\mathrm{HO}$

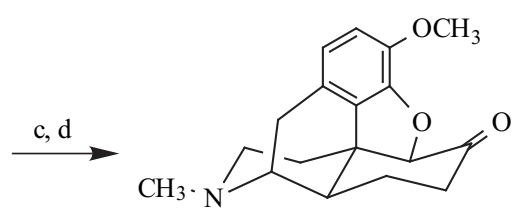

(19)

Fig. (23).

(a) $\mathrm{BF}_{3} \bullet \mathrm{OEt}_{2}$; (b) 3,5-dinitroperoxybenzoic acid $\left(\mathrm{CH}_{2} \mathrm{Cl}_{2}\right)$; (c) TPAP, NMO; (d) Pd(OH) $)_{2}, \mathrm{H}_{2}, \mathrm{H}_{2} \mathrm{CO}$.

finally, (4) removal of the dibenzylsuberate (DBS) protecting group by hydrogenolysis in the presence of formaldehyde (in $34 \%$ yield for the four steps; Fig. (23)).

\section{7: JAMES D. WHITE, PETER HRNCIAR AND FRANK STAPPENBECK [14]}

The challenge of an asymmetric synthesis, having been met by Chang Y. Hong, Noriyuki Kado and Larry E. Overman, as noted above, was next undertaken by James D. White, Peter Hrnciar and Frank Stappenbeck. The synthesis described yields the enantiomer of codeine. Further, as will be seen (vide infra), in addition to introduction of asymmetry at an early stage through reduction of an alkene with hydrogen in the presence of a chiral, homogeneous catalyst, this synthesis sets itself apart by utilizing a carbene insertion reaction to produce a quaternary center.

The synthesis itself begins [Fig. (24)] with a Stobbe type condensation between 3-hydroxy-4-methoxybenzaldehyde (isovanillin) and dimethylsuccinate, partial hydrolysis and reduction of the condensation product with hydrogen in the presence of a rhodium catalyst prepared from a cyclooctadiene (COD) rhodium chloride catalyst,
$[\mathrm{Rh}(\mathrm{COD}) \mathrm{Cl}]_{2}$, and the bisphosphine dimethylketal (-)$(4 R, 5 R)$-MOD-DIOP (30) to give 31 in $100 \%$ yield and with $94 \%$ ee.

Following bromination of the half ester $\mathbf{3 1}$ (which served to block the most reactive site), Friedel- Crafts cyclization, reductive dehalogenation and hydrolysis of the resulting ester yielded the tetralone 32 which was produced in $70 \%$ yield (for the four steps). Condensation of the tetralone with methyl formate ( $\alpha$ - to the carbonyl and with lactol formation) ( $85 \%$ ) followed by a second condensation with methyl vinyl ketone (95\%) led to the ketolactone (33). Further reaction of $\mathbf{3 3}$ with sodium hydroxide in aqueous THF converted 33 to the product of the Robinson annulation which was followed by decarboxylation to give the tricyclic ketone (34) (95\%); Fig. (25).

The ketoacid (34) was converted to the methyl ester with diazomethane and brominated with $\mathrm{Br}_{2}$ in dichloromethane in the presence of sodium bicarbonate to yield the dibromide, 35 (80\% for the two steps). Treatment of the $\alpha$ bromoenone (35) with 1,8-diazabicyclo[5.4.0]undec-7-ene (DBU) resulted in closure of the furan ring and formation of the tetracycle 36 which was isolated in 90\% yield; Fig. (26).<smiles>COc1ccc(C=O)cc1O</smiles><smiles>COc1ccc(C[C@H](C)C(=O)O)cc1O</smiles><smiles>COc1c(C)cc(P(C[C@H]2OC(C)(C)O[C@@H]2CP(c2cc(C)c(OC)c(C)c2)c2cc(C)c(OC)c(C)c2)c2cc(C)c(OC)c(C)c2)cc1C</smiles>

(31)

Fig. (24).

(a) dimethylsuccinate, $\mathrm{H}^{+}$, methanol, partial hydrolysis; (b) $\mathrm{H}_{2},[\mathrm{Rh}(\mathrm{COD}) \mathrm{Cl}]_{2},(-)-(4 R, 5 R)-\mathrm{MOD}-\mathrm{DIOP}(30)$, THF, methanol. 
<smiles>COc1ccc(C[C@H](CC(=O)O)C(C)=O)cc1O</smiles>

(31)<smiles>COc1ccc2c(c1O)C1=CC(=O)CC[C@H]1[C@H](C(=O)O)C2</smiles><smiles>COc1cc(Br)c(C[C@H](CC(=O)O)C(=O)O)cc1O</smiles>

$\mathrm{OH}$<smiles>COc1ccc2c(c1O)C(=O)[C@@]1(CCC(C)=O)C(O)OC(=O)[C@H]1C2</smiles><smiles>COc1ccc2c(c1O)C(=O)C[C@H](C=O)C2</smiles>

(32)<smiles>[Te][Te]</smiles><smiles>COc1ccc2c(c1O)C(=O)C1C(O)OC(=O)[C@@H]1C2</smiles>

Fig. (25).

(a) $\mathrm{Br}_{2}, \mathrm{CH}_{3} \mathrm{CO}_{2} \mathrm{H}$; (b) $\mathrm{CH}_{3} \mathrm{SO}_{3} \mathrm{H}, \mathrm{P}_{2} \mathrm{O}_{5}$ for the cyclization and $\mathrm{CH}_{3} \mathrm{OH}, \mathrm{NaHCO}_{3}, 10 \% \mathrm{Pd} / \mathrm{C}, \mathrm{H}_{2}, 1$ atm, room temp for the reduction, hydrolysis with $\mathrm{LiOH}$; (c) $\mathrm{KH}$ and $\mathrm{HCO}_{2} \mathrm{CH}_{3}$ in THF; (d) $\mathrm{Et}_{3} \mathrm{~N}, \mathrm{CH}_{2}=\mathrm{CHCOCH}_{3}, \mathrm{CH}_{2} \mathrm{Cl}_{2}$; (e) aq THF, $\mathrm{NaOH}$.

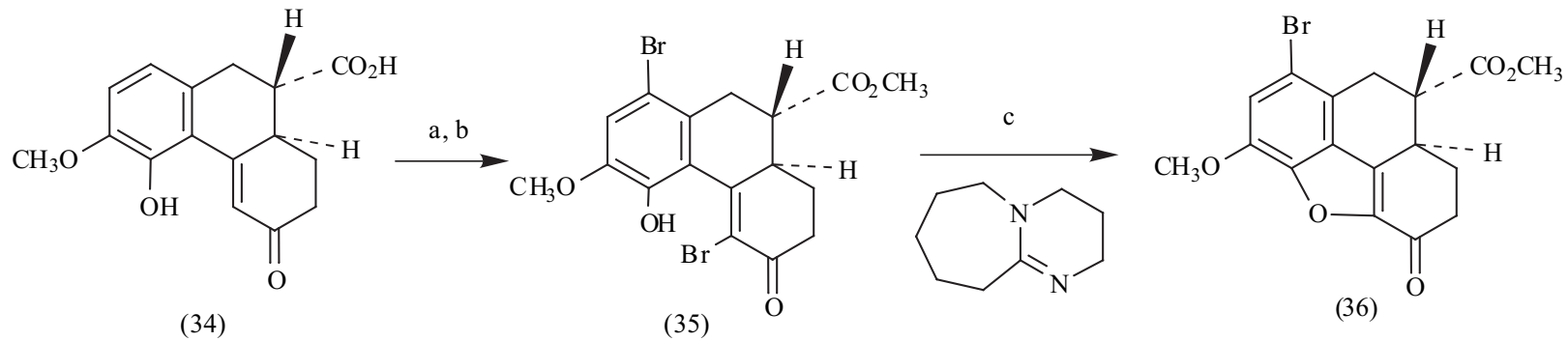

Fig. (26).

(a) $\mathrm{CH}_{2} \mathrm{~N}_{2}, \mathrm{Et}_{2} \mathrm{O}$; (b) $\mathrm{CH}_{2} \mathrm{Cl}_{2}, \mathrm{NaHCO}_{3}, \mathrm{Br}_{2}$; (c) $\mathrm{DBU}$ (shown), $\mathrm{C}_{6} \mathrm{H}_{6}, 50{ }^{\circ} \mathrm{C}$.

Reduction of the ketone (36) with sodium borohydride yielded, exclusively, the 6- alpha alcohol (37) which underwent hydrogenation (and hydrogenolysis) to the tetracyclic hydroxyester 38; Fig. (27).
When the hydroxyester $\mathbf{3 8}$, in chloroform, was treated with dimethoxymethane $\left[\mathrm{CH}_{2}\left(\mathrm{OCH}_{3}\right)_{2}\right]$ in the presence of phosphorus pentoxide the secondary hydroxyl was converted into its monomethyl ether (MOM) $(80 \%)$ and this ester,<smiles>COc1cc(Br)c2c3c4c(oc13)[C@H](C(C)=O)C4CCC2=O</smiles>

(36)

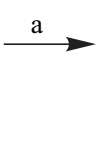

$\mathrm{CH}_{3} \mathrm{O}$<smiles></smiles>

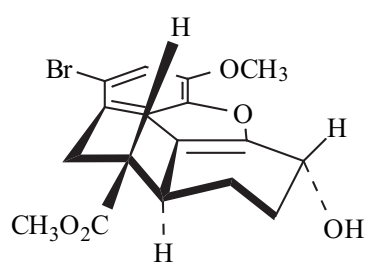

(37)<smiles>C#CC1Oc2c(OC)ccc3c2C12C[C@H](C(=O)OC)[C@H]2CCC3O</smiles><smiles>COc1ccc2c3c1OC1(CCC(O)C31)[C@H](C(C)=O)C2</smiles>

(38)

Fig. (27).

(a) $\mathrm{NaBH}_{4}\left(\mathrm{CH}_{3}\right)_{2} \mathrm{CHOH} / \mathrm{CHCl}_{3}$; (b) $\mathrm{CH}_{3} \mathrm{OH}, \mathrm{NaHCO}_{3}, 10 \% \mathrm{Pd} / \mathrm{C}, \mathrm{H}_{2}$. 


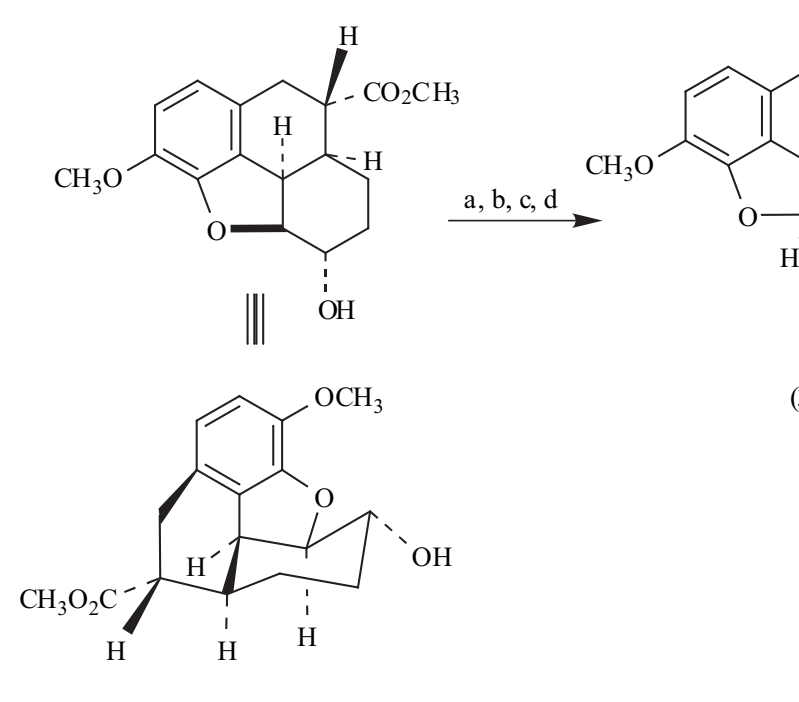

(38)

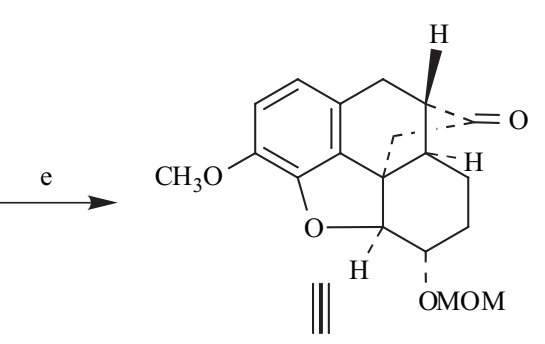

(39)

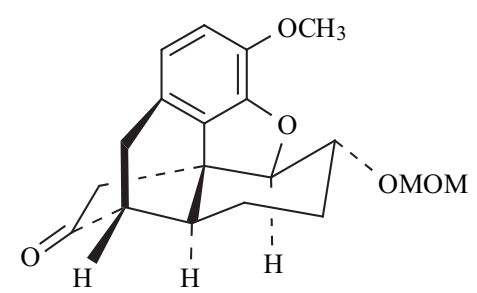

Fig. (28).

(a) $\mathrm{CH}_{2}\left(\mathrm{OCH}_{3}\right)_{2}, \mathrm{P}_{2} \mathrm{O}_{5}, \mathrm{CHCl}_{3}$; (b) $\mathrm{LiOH}$, THF (aq); (c) (ClCO) $)_{2}, \mathrm{C}_{6} \mathrm{H}_{6}$; (d) $\mathrm{CH}_{2} \mathrm{~N}_{2}, \mathrm{Et}_{2} \mathrm{O}$; (e) $\mathrm{Rh}_{2}\left(\mathrm{O}_{2} \mathrm{CCH}_{3}\right)_{4} \mathrm{CH}_{2} \mathrm{Cl}_{2}$.

with lithium hydroxide in aqueous THF readily underwent saponification to the corresponding carboxylic acid (99\%). Treatment of the latter with oxalyl chloride in benzene and then removal of the benzene and unreacted oxalyl chloride at reduced pressure yielded the corresponding acid chloride which was dissolved in ether. When the ethereal solution of acid chloride was treated with diazomethane methane in ether the diazo ketone (39) was produced (63\% for the two steps). Now, the diazo ketone in dichloromethane, on treatment with a catalytic amount of rhodium acetate dimer yielded $(50 \%)$ the carbene insertion product 40 ; Fig. (28).
When 40 was converted to a mixture of $(E)$ - and $(Z)$ oximes $(90 \%)$ and thence to the corresponding $p$ bromobenzenesulfonate esters (brosylates) (62\%) [Fig. (29)], it was found that Beckmann rearrangement to the lactam 41 (and its regioisomer in the ratio 11:1) was effected on exposure to acetic acid.

$\mathrm{N}$-methylation of the lactam (41) was carried out by $\mathrm{N}$ deprotonation with sodium hydride and treatment of the anion with iodomethane in benzene. Then removal of the MOM group with $\mathrm{HBr}$ in acetonitrile was followed by oxidation with periodinane (Dess-Martin Reagent [1,1,1-

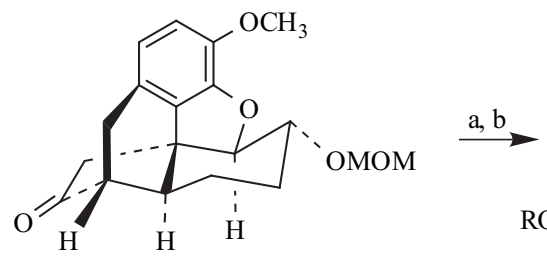

(40)

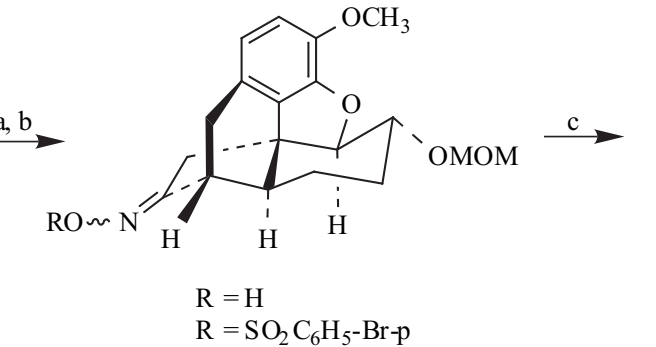

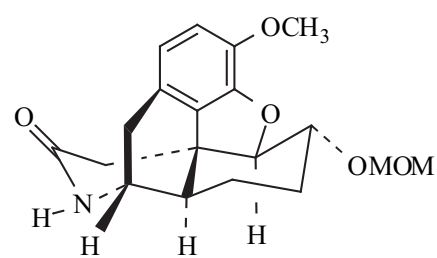

(41)

Fig. (29).

(a) $\mathrm{H}_{2} \mathrm{NOH} \mathrm{HCl}, \mathrm{NaO}_{2} \mathrm{CCH}_{3}$, methanol; (b) $\mathrm{CH}_{2} \mathrm{Cl}_{2}$, $p$-dimethylaminopyridine (DMAP), $\mathrm{Et}_{3} \mathrm{~N}, p$ - $\mathrm{BrC}_{6} \mathrm{H}_{4} \mathrm{SO}_{2} \mathrm{Cl}_{\text {; }}(\mathrm{c}) \mathrm{CH}_{3} \mathrm{CO}_{2} \mathrm{H}$ followed by $\mathrm{NaHCO}_{3}$ neutralization.

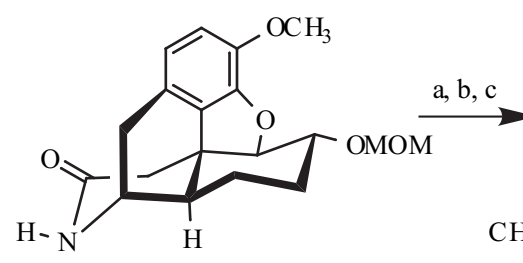

(41)

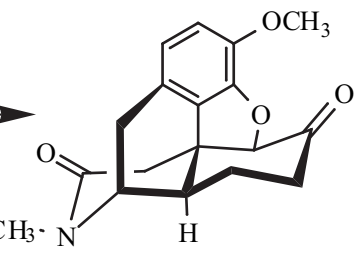

(42)

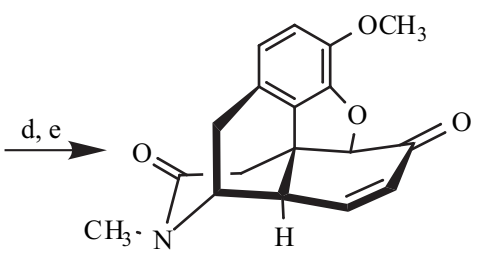

(43)

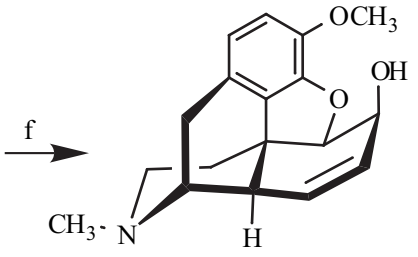

(2)

Fig. (30).

(a) $\mathrm{NaH}, \mathrm{CH}_{3} \mathrm{I}, \mathrm{C}_{6} \mathrm{H}_{6}$; (b) $\mathrm{HBr}, \mathrm{CH}_{3} \mathrm{CN}$; (c) $\mathrm{CHCl}_{3}$, Dess-Martin periodinane; (d) $\mathrm{C}_{6} \mathrm{H}_{5} \mathrm{SeCl}, \mathrm{CH}_{3} \mathrm{SO}_{3} \mathrm{H}, \mathrm{CH}_{2} \mathrm{Cl}_{2}$; (e) $\mathrm{NaIO}_{4}$; (f) $\mathrm{LiAlH}_{4}$, THF. 
triacetoxy-1,1-dihydro-1,2-benziodoxol-3(1H)-one]) in chloroform to yield the ketolactam (42) in $90 \%$ overall yield for the three steps; Fig. (30).

The ketolactam (42) was then treated with phenylselenyl chloride in the presence of methanesulfonic acid and the $\alpha$ phenylselenyl group introduced. Without isolation, elimination of the selenide was then be effected by oxidation with sodium periodate at room temperature to produce the $\alpha, \beta$-unsaturated ketone $\mathbf{4 3}$ in $65 \%$ for the two steps. Finally, treatment of $\mathbf{4 3}$ with lithium aluminum hydride in THF reduced both the keto group and the lactam to produce the optical antipode of codeine (2) which could, as previously described (vide supra), be demethylated with pyridinum hydrochloride to the mirror image isomer of morphine (1); Fig. (30).

\section{8: DIRK TRAUNER, JAN W. BATS, ANDREAS WERNER, AND JOHANN MULZER [15]}

Although bimolecular nucleophilic substitution $\left(\mathrm{S}_{\mathrm{N}} 2\right)$ and single electron transfer (SET) processes are well known, the generation of (-)-codeine in this synthesis makes use of "unusual" examples of these processes.

The synthesis presented here began with 4-(3,4dimethoxyphenyl)butanoic acid which, on chlorination in acetic acid produced the corresponding 4-(2-chloro-4,5-dimethoxy)butanoic acid (44) in $99 \%$ yield. Treatment of $\mathbf{4 4}$ with oxalyl chloride in benzene at reflux to form the acid chloride and then with tin (IV) chloride in the same solvent at $0{ }^{\circ} \mathrm{C}$ produced the corresponding tetralone $(\mathbf{4 5})(71 \%)$. Reaction of $\mathbf{4 5}$ with methyl formate in the presence of sodium methoxide generated the formyl derivative (46). Now activated for Robinson annulation, $\mathbf{4 6}$ was condensed with methyl vinyl ketone in the presence of triethylamine to produce (after elimination) the mixture of racemic alkenone 47 (81\%) and 48 (8\%); Fig. (31).

The racemic mixture 47 was resolved by chromatography on cellulose triacetate (methanol as eluent) and it was found that the undesired enantiomer, i.e. $(+)-47$, in the presence of base was reconverted to the mixture of racemic $\mathbf{4 7}$ and $\mathbf{4 8}$. Although much work was subsequently done with racemic 47 (to optimize procedures) it is clear that chiral material could have been used to the same end.

When 47 , in THF, was added to a reaction mixture composed of the cuprate product derived from addition of vinylmagnesium chloride to copper (I) iodide (CuI) in THF and that was followed by trimethylsilyl chloride and triethylamine, the TMS derivative of the substitution product (49) was isolated in $84 \%$ yield; Fig. (32). The reaction carried out on racemic material produced a crystalline adduct. The reaction carried out on chiral material produced an oil (also chiral).

When 49 was treated with N-bromosuccinimide in THF at low temperature a 3:1 mixture of $\alpha$-bromoketones was obtained in $81 \%$ yield. The favored isomer, $\mathbf{5 0}(60 \%)$, had the aryl and bromine groups diaxial and the vinyl group equatorial. The minor isomer, 51 (21\%), also had the bromine axial but now the vinyl was axial and the aryl ring equatorial. The disfavored isomer could be dehalogenated to (49) and recycled; Fig. (32).

In DMF at $140{ }^{\circ} \mathrm{C}, \mathbf{5 0}$ underwent demethylation and dehalogenation with closure of the furan ring to (52). Then, protection of the ketone as the ethylene ketal was followed by functionalization of the carbon-carbon double bond and hydrogenolysis to remove the aromatic chlorine substituent.

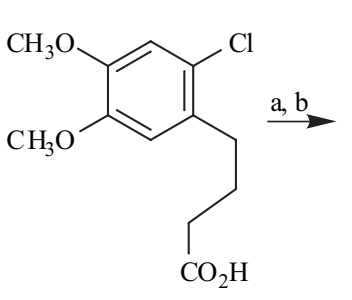

(44)

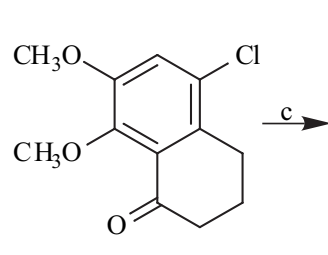

(45)

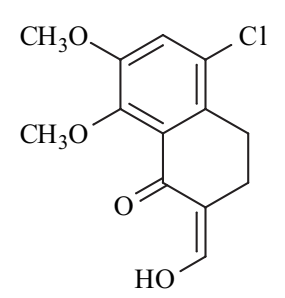

(46)

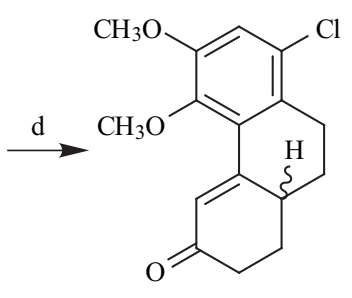

(47)<smiles>CC/C=C\Cl</smiles>

(48)

Fig. (31).

(a) $(\mathrm{COCl})_{2}, \mathrm{C}_{6} \mathrm{H}_{6}$; (b) $\mathrm{SnCl}_{4}, \mathrm{C}_{6} \mathrm{H}_{6}, 0{ }^{\circ} \mathrm{C}$; (c) $\mathrm{HCO}_{2} \mathrm{CH}_{3}, \mathrm{NaOCH}_{3}, \mathrm{C}_{6} \mathrm{H}_{6}$; (d) $\mathrm{CH}_{2}=\mathrm{CHCOCH}_{3}, \mathrm{Et}_{3} \mathrm{~N}, \mathrm{CH}_{3} \mathrm{OH}$ followed by $\mathrm{KOH}$ in aqueous dioxane.<smiles>CCc1c(Cl)cc(OC)c(OC)c1C1=CC(=O)CC[C@H]1CC</smiles>

(47)
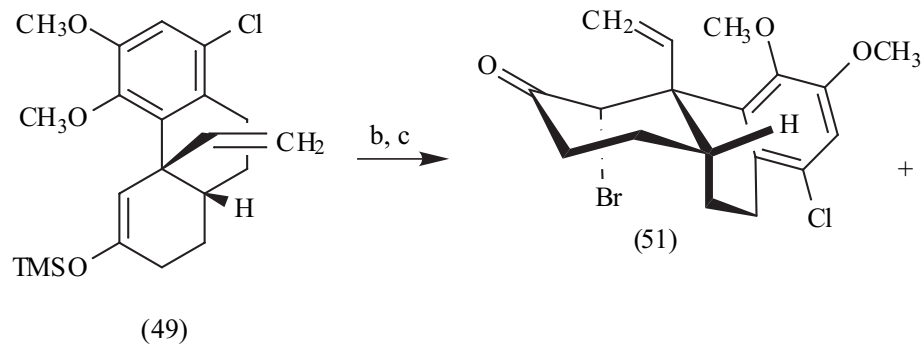

(51)

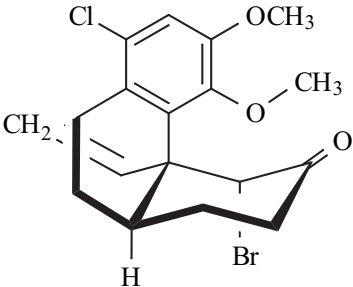

(50)

Fig. (32).

(a) $\mathrm{CH}_{2}=\mathrm{CHMgCl}$, CuI; followed by $\left(\mathrm{CH}_{3}\right)_{3} \mathrm{SiCl}, \mathrm{Et}_{3} \mathrm{~N}$; (b) N-bromosuccinimide, THF; (c) $\mathrm{Zn}$ and $\left(\mathrm{CH}_{3}\right)_{3} \mathrm{SiCl}, \mathrm{TMEDA}$. 


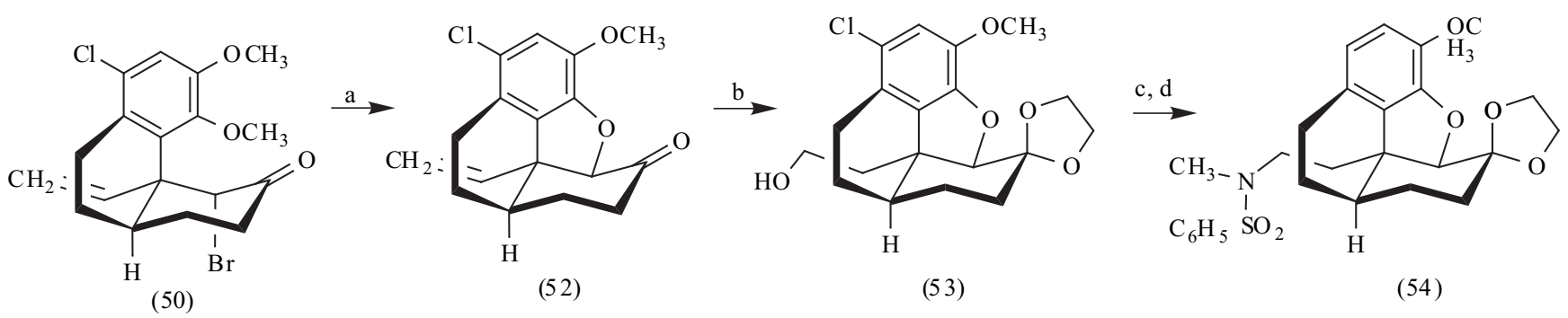

Fig. (33).

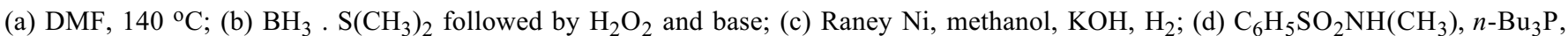
ADDP.

Thus, oxidative hydroboration of (52) produced the primary alcohol $53(70 \%)$ which underwent reductive dehalogenation of the aromatic ring $98 \%$ yield. Then, the primary hydroxyl was replaced with an N-methylbenzenesulfonamido group (in $81 \%$ yield), generating $\mathbf{5 4}$ by employing a variation of the Mitsunobo reaction. In this variation, the alcohol and $\mathrm{N}$-methylbenzenesulfonamide were brought into reaction using tri-n-butylphosphine and 1,1'azodicarbonyldipiperidine (ADDP); Fig. (33).

\section{1: HIROSHI NAGATA, NORIO MIYAZAWA AND KUNIO OGASAWARA [16]}

Although a vast literature utilizing the rearrangements of bicyclic alcohols exists, it is uncommon to find such rearrangements incorporated into a total synthesis of an alkaloid.

The lipase oxidation of norbornadiene (bicyclo[2.2.1] hepta-2,5-diene) and ring expansion reactions (using

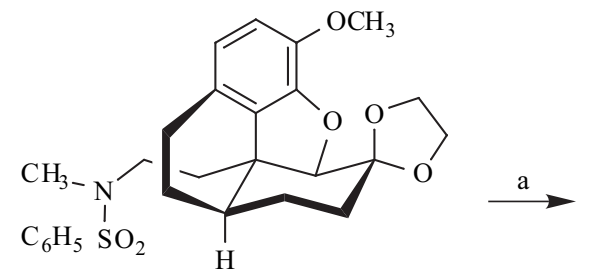

(54)

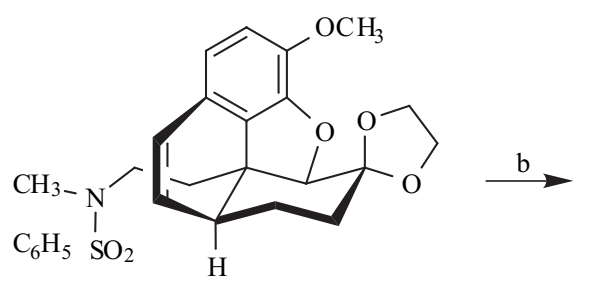

(55)

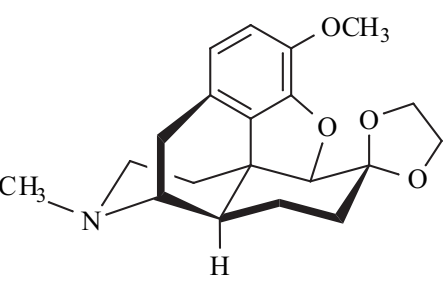

(56)

Fig. (34).

(a) NBS, $\mathrm{CCl}_{4},\left(\mathrm{C}_{6} \mathrm{H}_{5} \mathrm{CO}_{2}\right)_{2}$; (b) Li, $\mathrm{NH}_{3}$ (liquid), t-BuOH, THF.

Now, when the sulfonamide $\mathbf{5 4}$ was treated with $\mathrm{N}$ bromosuccinimide and a catalytic amount of dibenzoyl peroxide in refluxing carbon tetrachloride, halogenation and dehydrohalogenation occurred with the introduction of the carbon-carbon double bond as shown in $\mathbf{5 5}$ in $81 \%$ yield. Treatment of this styrene under the same conditions as Parker and Focas (vide supra) with lithium in liquid ammonia/THF effected the cyclization to the ketal $\mathbf{5 6}$ in $79 \%$ yield [Fig. (34)] and finally, hydrolysis in dilute aqueous $\mathrm{HCl}$ produced (-)-dihydrocodeinone which, as noted above, has been converted to both codeine (2) and morphine (1). diazomethane) on the products of that oxidation yielded, among other products, the chiral bicyclo[3.2.1] oct-3-ene-2one-6-ol (57), the MOM derivative of which began this synthesis [17].

When the enone $\mathbf{5 7}$ is treated with the product of the reaction of 1,2-dimethoxy-benzene (veratrol) with butyllithium (presumably mostly 3-lithioveratrol) in THF at $-78{ }^{\circ} \mathrm{C}$ the tertiary alcohol $\mathbf{5 8}$ is generated. On oxidation with pyridinium chlorochromate in dichloromethane the oxygen transposition occurs and the MOM ether of the bicyclo[3.2.1] oct-2-ene-2-(2,3-dimethyoxyphenyl)-4-one-6ol, 59, results in $81 \%$ yield for the two steps; Fig. (35).

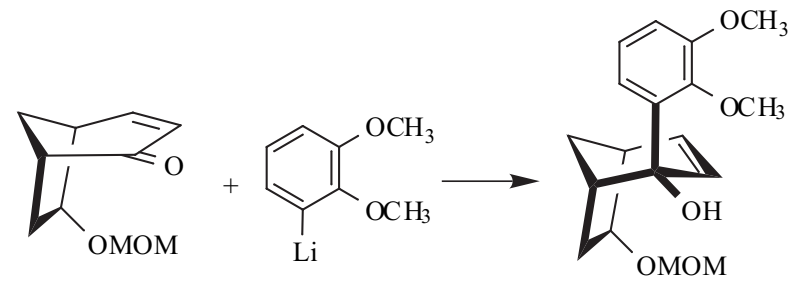

(57)
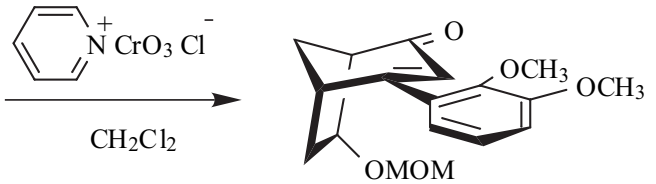

(59)

Fig. (35). 


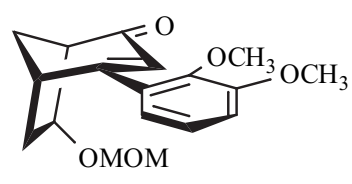

(59)
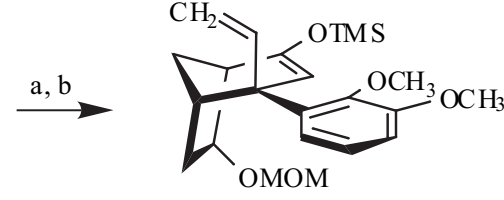

(60)

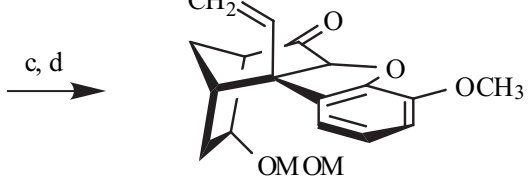

(61)

Fig. (36).

(a) $\mathrm{CH}_{2}=\mathrm{CHMgCl}, \mathrm{CuBr}-\left(\mathrm{CH}_{3}\right)_{2} \mathrm{~S}$; (b) $\left(\mathrm{CH}_{3}\right)_{3} \mathrm{SiCl}$, HMPA, THF; (c) NBS, $\mathrm{CH}_{2} \mathrm{Cl}_{2}$; (d) DMF reflux.

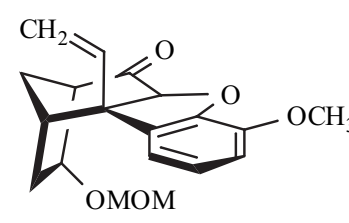

(61)

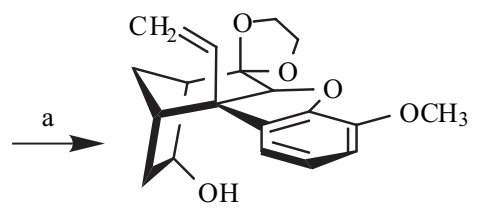

(62)

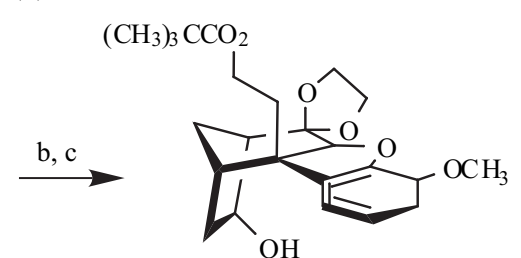

(63)

Fig. (37).

(a) $\left[\left(\mathrm{CH}_{3}\right)_{3} \mathrm{SiOCH}_{2}\right]_{2},\left(\mathrm{CH}_{3}\right)_{3} \mathrm{SiOSO}_{2} \mathrm{CF}_{3}, \mathrm{CH}_{2} \mathrm{Cl}_{2} ;$ (b) $\mathrm{BH}_{3} \bullet \mathrm{S}\left(\mathrm{CH}_{3}\right)_{2}$ followed by $\mathrm{H}_{2} \mathrm{O}_{2}, \mathrm{NaOH}$; (c) $\left(\mathrm{CH}_{3}\right)_{3} \mathrm{CCOCl}$, pyridine.

Then, as with Dirk Trauner, Jan W. Bats, Andreas Werner, and Johann Mulzer (vide supra), treatment of $\mathbf{5 9}$ with vinylmagnesium chloride in THF containing hexamethylphosphoramide (HMPA) in the presence of copper (I) bromide and trimethylsilyl chloride, resulted in addition of the vinyl group to the carbon at the terminus of the double bond (with formation of the enol) and silylation of the enol so generated produced $\mathbf{6 0}$ in $75 \%$ yield. Bromination of $\mathbf{6 0}$ with $\mathrm{N}$-bromosuccinimide in $\mathrm{CH}_{2} \mathrm{Cl}_{2}$ (in $99 \%$ yield) at the carbon $\alpha$-to the carbonyl and heating bromoketone product in refluxing $\mathrm{N}, \mathrm{N}$-di-methylformamide (vide supra) resulted in closure of the furan ring to produce $\mathbf{6 1}$ as a single diastereomer (in $82 \%$ yield); Fig. (36).
When the ketone $\mathbf{6 1}$ was treated with 1,2bis(trimethylsiloxy)ethane in the presence of trimethylsilyl triflate, both protection of the keto group and deprotection of the hydroxyl occurred to generate the hydroxyketal 62 in $71 \%$ yield. Then, oxidative hydroboration of the alkene generated the corresponding primary alcohol which was acylated with pivaloyl chloride (at the primary hydroxyl only) forming $\mathbf{6 3}$ in $63 \%$ yield (for the two steps); Fig. (37).

When the ester $\mathbf{6 3}$ was heated with ethylene glycol in benzene (Dean-Stark trap) with a trace of $p$-toluenesulfonic acid (HOTs) rearrangement to 64 occurred (50\% yield); Fig. (38). Finally, reduction of the ester 64 with lithium aluminum hydride generated the primary alcohol 65 and

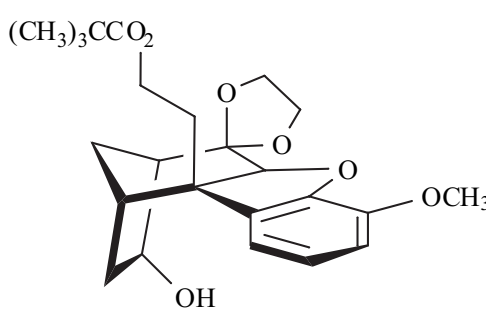

(63)

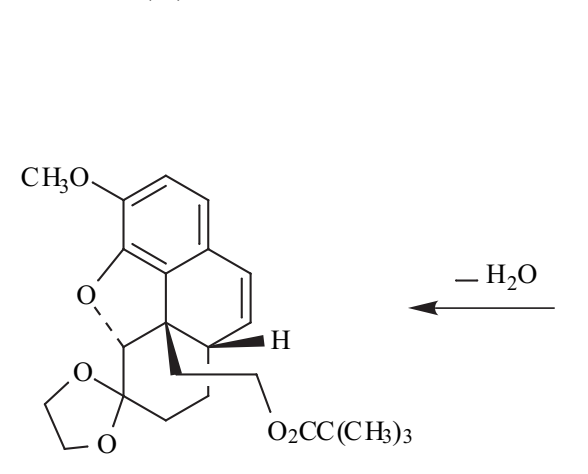

(64)
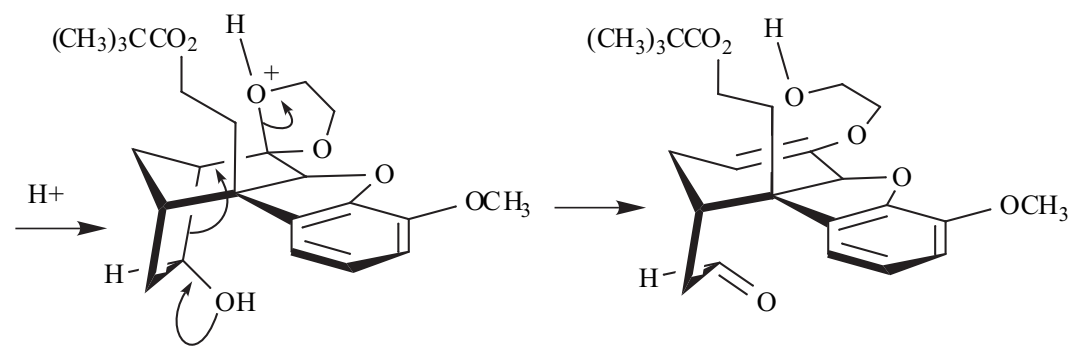
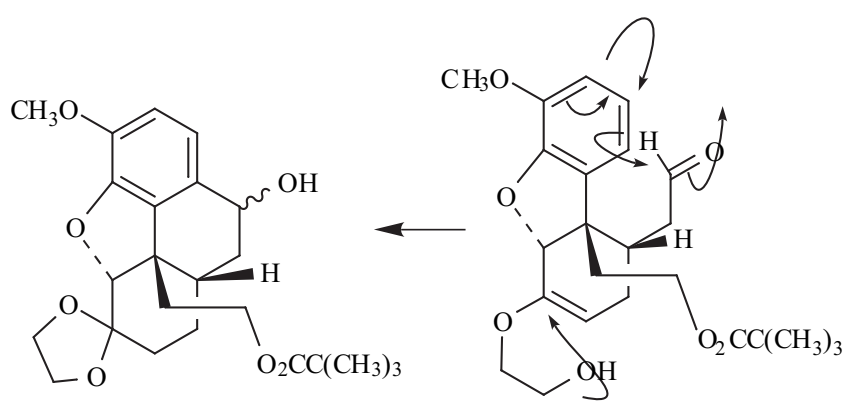

Fig. (38). Rearrangement of the bicyclo[3.2.1] system to a hydrophenanthrene. 


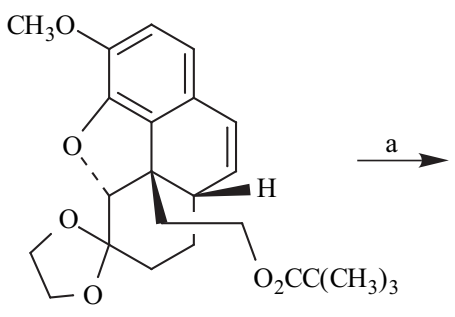

(64)

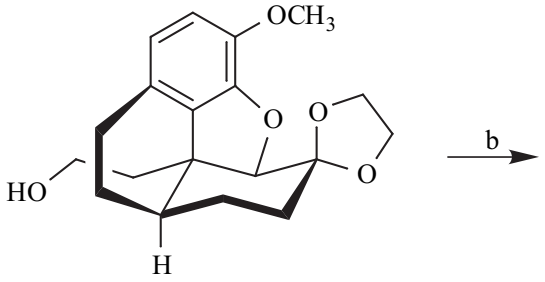

$(65)$

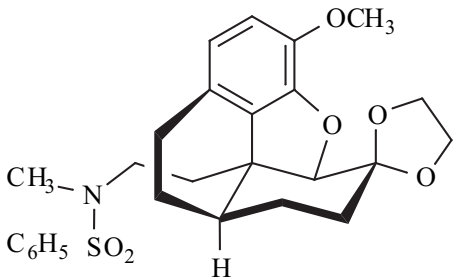

(53)

Fig. (39).

(a) $\mathrm{LiAlH}_{4}, \mathrm{THF}$; (b) $\mathrm{C}_{6} \mathrm{H}_{5} \mathrm{SO}_{2} \mathrm{NH}\left(\mathrm{CH}_{3}\right), n-\mathrm{Bu}_{3} \mathrm{P}$, ADDP.

following the work of Dirk Trauner, Jan W. Bats, Andreas Werner, and Johann Mulzer already shown in Fig. (33) (vide supra), replacement of the hydroxyl with an $\mathrm{N}$ methylbenzenesulfonamido group was effected, generat-ing 53; Fig. (39). Then, following the same protocol, the synthesis was completed.

\section{2: DOUGLASS F. TABER, TIMOTHY D. NEUBERT AND ARNOLD L. RHEINGOLD [18]}

This artful synthesis makes use of currently understood reactions set to a high standard. Thus, O-alkylation of 1,6dibromo-2-naphthol (66) with methyl iodide and subsequent copper (I) iodide catalyzed Ullman condensation of the dibromoether with sodium methoxide in the presence of collidine in refluxing methanol produced the trimethoxynaphthalene (67) in $89 \%$ yield. As anticipated, reduction of the aromatic ring bearing the single $\beta$-methoxy substituent occurred and the enol ether formed was hydrolyzed with aqueous $\mathrm{HCl}$ whereupon it was immediately treated with dimethyl carbonate and sodium methoxide in refluxing methanol to generate the corresponding $\beta$-ketocarboxylic acid ester (68) in $56 \%$ yield for the two steps; Fig. (40).
The dianion derived from $\mathbf{6 8}$ was then allowed to react with $(Z)$-1,3-dibromo-2-methyl-1-propene [which was prepared from the corresponding (Z)-1-bromo-2-methyl-1propene-3-ol by reaction with dibromotriphenylphosphene] and the resulting adduct subjected to hydrolysis and decarboxylation to form the alkylated tetralone $(\mathbf{6 9})$ in $80 \%$ yield. When the tetralone (69) was treated with $(S, S)-(-)-$ hydrobenzoin a pair of diasteromeric ketals (70) and (71), which were separable on chromatography, formed in $86 \%$ yield. The undesired isomer (70) could be recycled to 69 while generation of the alkylidene carbene from 71 led to insertion into the benzylic $\mathrm{C}-\mathrm{H}$ bond forming $\mathbf{7 2}$ in $77 \%$ yield and hydrolysis of that product to regenerate the chiral hydrobenzoin yielded enantiomerically pure ketone (73); Fig. (41).

When the tricyclic tetralone $\mathbf{7 3}$ was reduced with lithium tri-sec-butylborohydride (L-selectride) in THF at $0{ }^{\circ} \mathrm{C}$, the cis-alcohol 74 was formed (in 97\% yield) with hydride delivery from the least hindered side occurring exclusively. Then, Mitsunobu coupling with the azide transfer reagent diphenylphosphonic azide in the presence of diethylazodicarboxylate (DEAD) and triphenylphosphine in THF to $\mathbf{7 5}$ followed by reduction with lithium aluminum hydride and a Schotten-Bauman reaction with benzenesulfonyl chloride in<smiles>COc1ccc2c(OC)c(OC)ccc2c1</smiles>

(66)

(67)<smiles>COC(=O)[C@H]1C(=O)CCc2c1ccc(OC)c2OC</smiles><smiles>COc1ccc2c(c1OC)CCC(=O)C2</smiles>

(68)

Fig. (40).

(a) $\mathrm{CH}_{3} \mathrm{I}, \mathrm{K}_{2} \mathrm{CO}_{3},\left(\mathrm{CH}_{3}\right)_{2} \mathrm{NCHO}$; (b) $\mathrm{NaOCH}_{3}, \mathrm{CuI}, \mathrm{CH}_{3} \mathrm{OH}$, and 2,4,6-trimethylpyridine; (c) $\mathrm{Na}$, EtOH, reflux; (d) $\left(\mathrm{CH}_{3} \mathrm{O}\right)_{2} \mathrm{CO}, \mathrm{CH}_{3} \mathrm{OH}$, $\mathrm{NaOCH}_{3}$. 


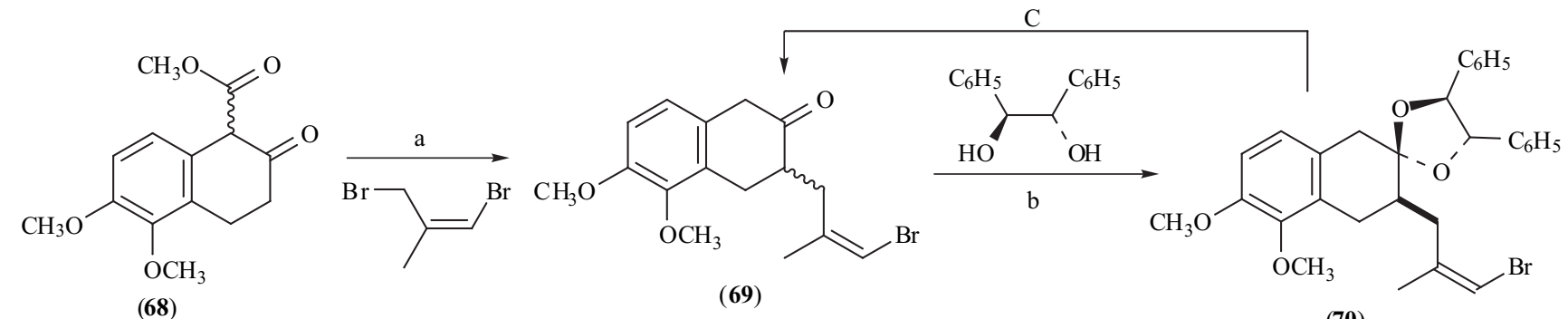<smiles>COc1ccc2c(c1OC)C1C=C(C)CC1C(=O)C2</smiles>

(73)

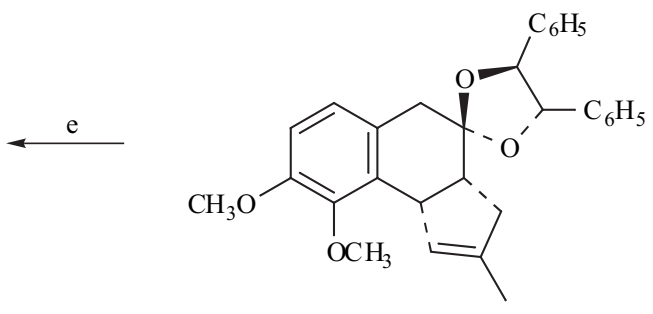

(72)

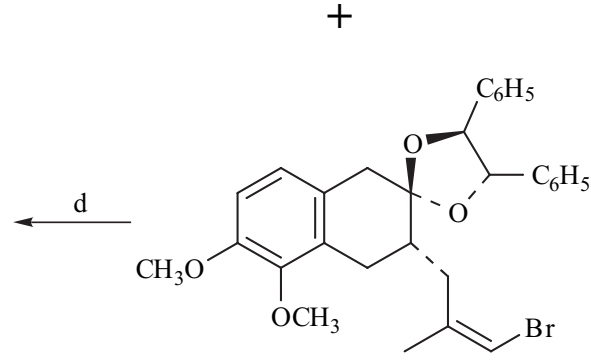

(71)

Fig. (41).

(a) 2 equiv. lithium diisopropylamide (LDA), THF $0{ }^{\circ} \mathrm{C}$; (b) $p$-toluenesulfonic acid, $\mathrm{HC}(\mathrm{OEt})_{3}, \mathrm{CH}_{2} \mathrm{Cl}_{2}$; (c) $\mathrm{CH}_{3} \mathrm{CO}_{2} \mathrm{H}, \mathrm{H}_{2} \mathrm{O}$, reflux; (d) $\mathrm{K} \mathrm{N}\left[\mathrm{Si}\left(\mathrm{CH}_{3}\right)_{3}\right]_{2}, \mathrm{Et}_{2} \mathrm{O}$; (e) $\mathrm{CH}_{3} \mathrm{CO}_{2} \mathrm{H}, \mathrm{H}_{2} \mathrm{O}$, reflux.<smiles>COc1ccc2c(c1OC)C1C=C(C)CC1C(=O)C2</smiles>

(73)<smiles>COc1ccc2c(c1OC)C1C=C(C)CC1C(O)C2</smiles>

(74)<smiles>COc1ccc2c(c1OC)C1C=C(C)CC1[C@@H](N)C2</smiles>

(75)<smiles>CCCCN([C@H]1Cc2ccc(OC)c(OC)c2C(C=O)C1CC(C)=O)S(=O)(=O)c1ccccc1</smiles>

(78)

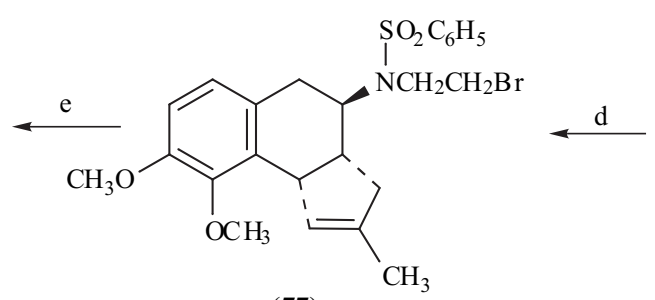

(77)<smiles>CCCCCOS(=O)(=O)N[C@H]1Cc2ccc(OC)c(OC)c2C2C=C(C)CC21</smiles>

(76)

Fig. (42).

(a) $\mathrm{Li} \mathrm{HB}\left[\mathrm{CH}\left(\mathrm{CH}_{3}\right) \mathrm{CH}_{2} \mathrm{CH}_{3}\right]_{3}$ (L-selectride), THF; (b) $\left[\left(\mathrm{C}_{6} \mathrm{H}_{5} \mathrm{O}\right)_{2} \mathrm{P}(\mathrm{O}) \mathrm{N}_{3},\left(\mathrm{EtO}_{2} \mathrm{CN}\right)_{2},\left(\mathrm{C}_{6} \mathrm{H}_{5}\right)_{3} \mathrm{P}, \mathrm{THF}\right.$; (c) LiAlH 4 , EtOH/Et $2 \mathrm{O}$ and $\mathrm{C}_{6} \mathrm{H}_{5} \mathrm{SO}_{2} \mathrm{Cl}, \mathrm{Et}_{3} \mathrm{~N}$; (d) $\left(\mathrm{BrCH}_{2}\right)_{2}, 1 \mathrm{~N} \mathrm{NaOH}, \mathrm{Bu}_{4} \mathrm{~N}^{+} \mathrm{Br}^{-}$, toluene; (e) $\mathrm{O}_{3}, \mathrm{CH}_{2} \mathrm{Cl}_{2},\left(\mathrm{C}_{6} \mathrm{H}_{5}\right)_{3} \mathrm{P}$.

the presence of triethylamine gave the sulfonamide $\mathbf{7 6}$ (in $43 \%$ yield for the three steps). Finally, alkylation at nitrogen with 1,2-dibromoethane (using tetrabutyl-ammonium bromide as the phase transfer catalyst) and ozonolysis in dichloromethane prepared the system (78) for selective ring formation to the morphinane system; Fig. (42).

Treatment of $\mathbf{7 8}$ with potassium carbonate in toluene, again under phase transfer conditions with tetrabutylammonium bromide effected, first, the cyclization with displacement of the bromide anion and then, second, the aldol cyclization with dehydration producing $\mathbf{7 9}$ in $92 \%$ yield for the two steps. Reduction of the carbonyl of the enone with sodium borohydride to $\mathbf{8 0}$ and exposure of the latter to boron tribromide resulted in furan ring formation and isolation of $\mathbf{8 1}$ in $70 \%$ yield. The phenylsulfonyl protecting group of $\mathbf{8 1}$ was removed in $78 \%$ yield to generate $\mathbf{8 2}$ by treatment of the former with sodium bis(2methoxyethoxy)aluminum hydride (Red-Al) in toluene. Protection of $\mathbf{8 2}$ as the carboethoxy amide by treatment with ethyl chloroformate and triethylamine in dichloromethane and then oxidation to the epoxide with hydrogen peroxide in the presence of a methyl trioctylammonium tetrakis 


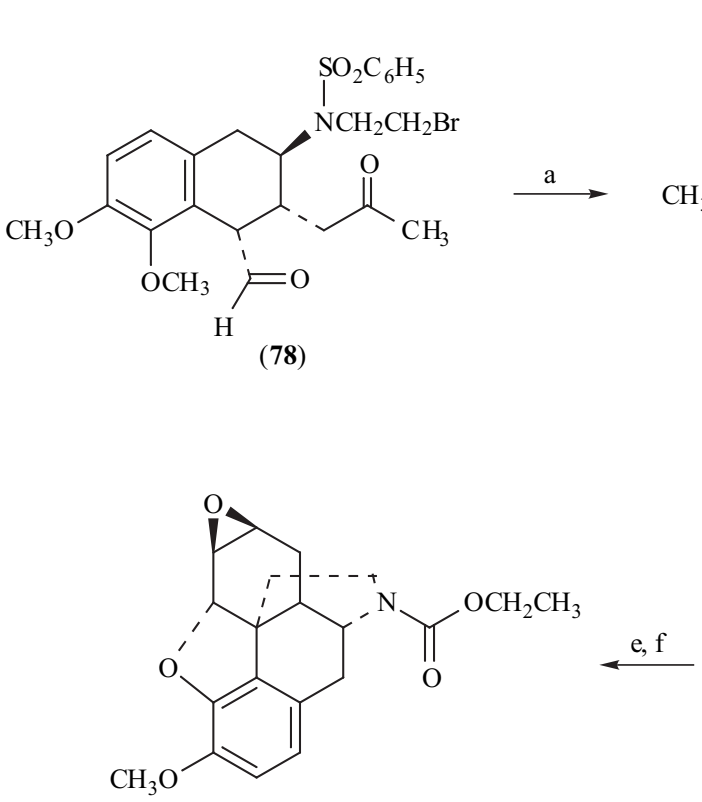

(83)

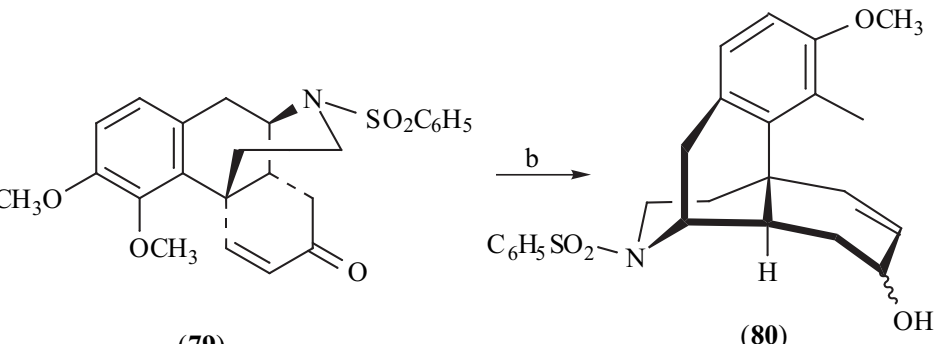

(79)

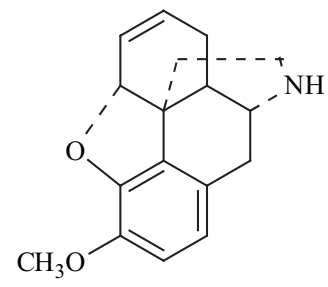

$(\mathbf{8 2})$

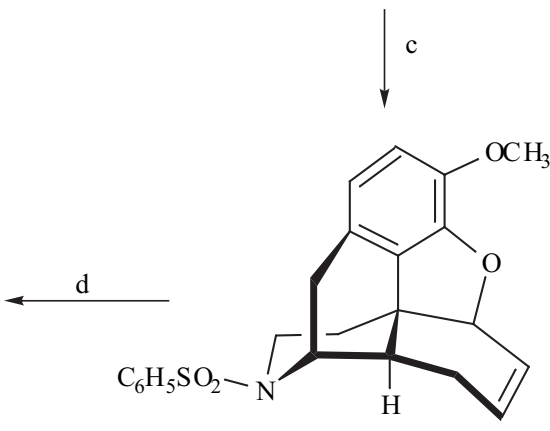

(81)

Fig. (43).

(a) $\mathrm{K}_{2} \mathrm{CO}_{3}, \mathrm{Bu}_{4} \mathrm{~N}^{+} \mathrm{Br}^{-}$, toluene; (b) $\mathrm{NaBH}_{4}, \mathrm{EtOH}$; (c) $\mathrm{BBr}_{3}, \mathrm{CH}_{2} \mathrm{Cl}_{2},-78{ }^{\circ} \mathrm{C}$; (d) $\mathrm{Na}^{+}-\mathrm{AlH}\left(\mathrm{OCH}_{2} \mathrm{CH}_{2} \mathrm{OCH}\right)_{2}$ [bis $(2-$ methoxyethoxy)aluminum hydride (Red-Al)]; (e) $\mathrm{ClCO}_{2} \mathrm{Et}, \mathrm{Et}_{3} \mathrm{~N}$; (f) $\left[\left(\mathrm{C}_{8} \mathrm{H}_{17}\right)_{3} \mathrm{NCH}_{3}\right]^{+}\left[\mathrm{PO}_{4}\left[\mathrm{~W}(\mathrm{O})\left(\mathrm{O}_{2}\right)_{2}\right]_{4}^{-3}, \mathrm{H}_{2} \mathrm{O}_{2}\right.$, dichloroethane.

(diperoxotungsto)phosphate catalyst to produce $\mathbf{8 3}$ in $75 \%$ yield; Fig. (43).

To finish the synthesis, [Fig. (44)] the epoxide 83 was opened regioselectively with diphenyldiselenide and sodium borohydride in ethanol to $\mathbf{8 4}$ (in $75 \%$ yield) which was then oxidized with sodium metaperiodate in THF and water to the corresponding selenoxide so that elimination, on treatment of the selenoxide with sodium carbonate in toluene, would produce 85 (56\%). Manganese dioxide oxidation of the allylic alcohol in dichloromethane, followed by lithium aluminum hydride reduction produced (-)-codeine (2) in 75\% yield and a final O-demethylation in $89 \%$ yield with boron tribromide generated (-)-morphine (1).

\section{2: BARRY M. TROST AND WEIPING TANG [19]}

As pointed out earlier and as noted here, there is continuing interest in developing total synthetic routes because of the broad range of pharmacological properties of these and related compounds.

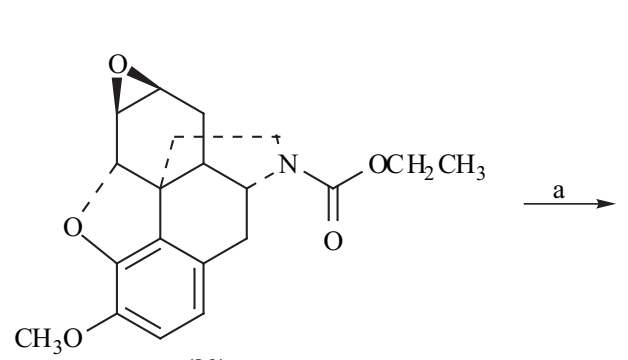

(83)

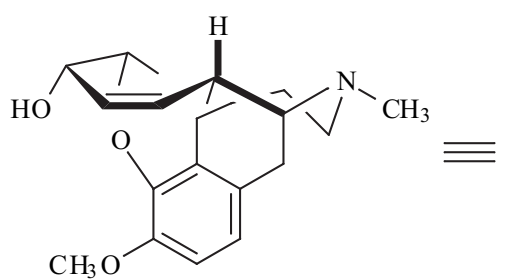

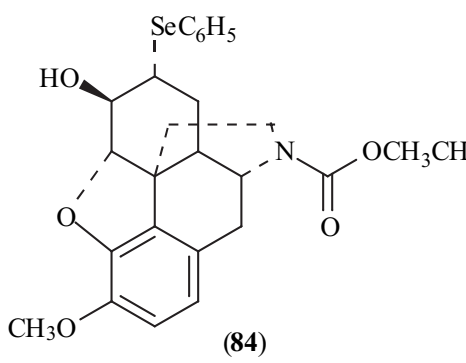

(84)<smiles>COC(=O)N1CC2C(C)C=C[C@H](O)C2Oc2c(OC)ccc3c2C31F</smiles>

(85)<smiles>CN1C=CC(O)C2Oc3c(O)ccc4c3C2(C)C(C4)C1</smiles>

(1)<smiles>COc1ccc2c3c1OC1C(O)C=CC(C2)C31C</smiles>

Fig. (44).

(a) $\left(\mathrm{C}_{6} \mathrm{H}_{5} \mathrm{Se}\right)_{2}, \mathrm{NaBH}_{4}, \mathrm{EtOH}$; (b) $\mathrm{NaIO}_{4}, \mathrm{THF}, \mathrm{H}_{2} \mathrm{O}$; (c) $\mathrm{MnO}_{2}, \mathrm{CH}_{2} \mathrm{Cl}_{2}$; (d) $\mathrm{LiAlH}_{4}, \mathrm{THF}$; (e) $\mathrm{BBr}_{3}$. 

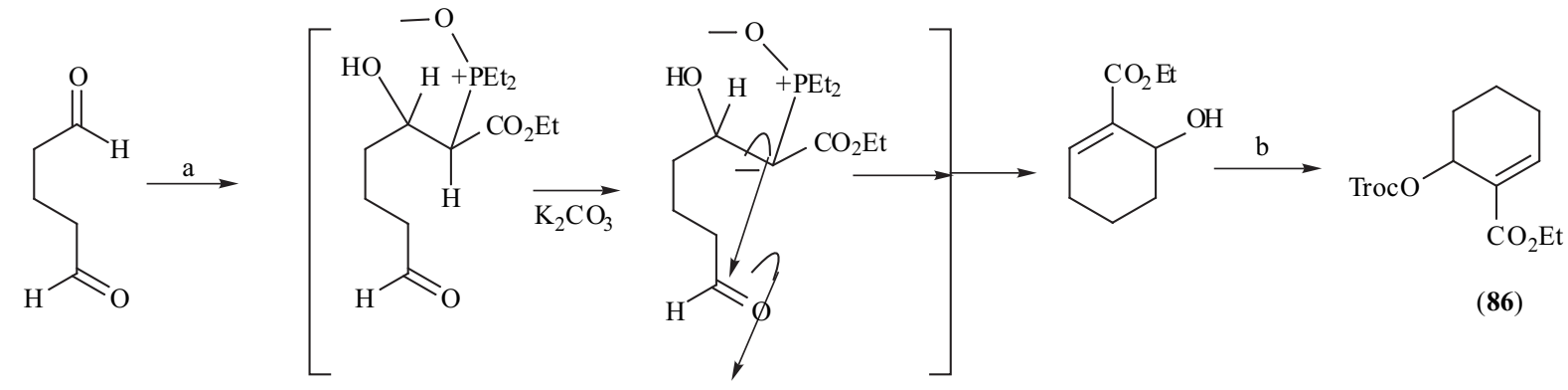

(86)

Fig. (45).

(a) $\left(\mathrm{CH}_{3} \mathrm{CH}_{2} \mathrm{O}\right)_{2} \mathrm{P}(\mathrm{O}) \mathrm{CHCO}_{2} \mathrm{CH}_{2} \mathrm{CH}_{3}, \mathrm{~K}_{2} \mathrm{CO}_{3}, \mathrm{H}_{2} \mathrm{O}$; (b) $\mathrm{CCl}_{3} \mathrm{CH}_{2} \mathrm{O}_{2} \mathrm{CCl}$, base.

The synthesis described here begins with the trichloroethyl chloroformate (Troc) derivative of the methyl ester of 6-hydroxycyclohexene-1-carboxylic acid (86), the alcohol, 1-carbomethoxy 1-cyclohexene 6-ol itself having been prepared via a Wittig-Horner reaction between gluteraldehyde and the Wadsworth-Emmons reagent, triethylphosphonacetate, [Fig. (45)] following the procedure of J. Villieras, M. Rambaud and M. Graff [20].

When this ester (86) was coupled with the bromovanallin, 2-bromo-3-hydroxy-4-methoxybenzaldehyde, (vide supra, Parker and Fokas) in the presence of a palladium catalyst and the chiral ligand $(+)-1(S), 2(S)$-Bis[2'(diphenylphosphine)benzamido]-1,2-diphenylethane (87), the aryl ether 88 was obtained; Fig. (46). with trimethylorthoformate in the presence of toluenesulfonic acid and the product of that reaction treated with diisobutylaluminum hydride (DIBAL-H) in toluene at -78 ${ }^{\circ} \mathrm{C}$ to form 89 in $85 \%$ yield (for the two steps). The alcohol thus generated was subjected to a variation of the Mitsunobu reaction. Treatment of $\mathbf{8 9}$ with triphenylphosphine, the cyanohydrin of acetone and diisopropyl azodicarboxylate (DIAD) in ether served to replace the hydroxyl group with a cyano function and then, with toluenesulfonic acid in $\mathrm{THF} / \mathrm{H}_{2} \mathrm{O}$ the ketal was hydrolyzed to generate 90. Then, this bromoaldehyde (90) underwent a Heck coupling reaction in the presence of palladium diacetate, 1,3-bis(diphenylphosphino)propane (dppp), and silver carbonate in toluene at<smiles>CCCOC1CCCC=C1C(=O)OCC</smiles>

(86)

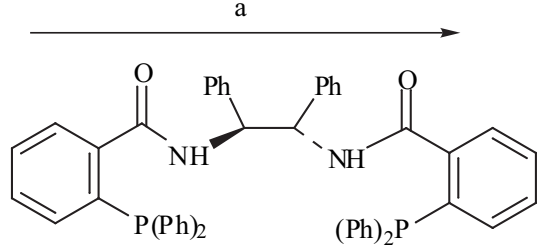

(87)<smiles>CCOC(=O)C1=CCCC[C@H]1Oc1c(OC)ccc(C=O)c1Br</smiles>

(88)

Fig. (46).

(a) $3 \%(87), 1 \%\left[\eta^{3}-\mathrm{C}_{3} \mathrm{H}_{3} \mathrm{PdCl}\right]_{2}, \mathrm{Et}_{3} \mathrm{~N}, \mathrm{CH}_{2} \mathrm{Cl}_{2}$.

The aldehydic functional group in the ether $\mathbf{8 8}$ was then protected as the dimethyl ketal by reaction of the aldehyde

$107{ }^{\circ} \mathrm{C}$ to yield the tricyclic furan 91 in $91 \%$ yield; Fig. (47).<smiles>CCOC(=O)C1=CCCC[C@H]1Oc1c(OC)ccc(C=O)c1Br</smiles>

(88)<smiles>COc1ccc(C(O)OC)c(Br)c1O[C@H]1CCCC=C1CO</smiles>

(89)<smiles>COc1ccc(C=O)c(Br)c1O[C@H]1CCCC=C1CC#N</smiles>

(90)<smiles>COc1ccc(C=O)c2c1O[C@H]1CCC=CC21CC#N</smiles>

(91)

Fig. (47).

(a) $\mathrm{CH}\left(\mathrm{OCH}_{3}\right)_{3}$, HOTs, $\mathrm{CH}_{3} \mathrm{OH}$; (b) DIBAL-H / toluene $-78{ }^{\circ} \mathrm{C}$; (c) $\left(\mathrm{C}_{6} \mathrm{H}_{5}\right)_{3} \mathrm{P}, \mathrm{CH}_{3} \mathrm{C}(\mathrm{OH})(\mathrm{CN}) \mathrm{CH}_{3},\left[\left(\mathrm{CH}_{3}\right)_{2} \mathrm{CHO}_{2} \mathrm{C}-\mathrm{N}\right]_{2}, \mathrm{Et}_{2} \mathrm{O}$; $(\mathrm{d})$ $\mathrm{THF} / \mathrm{H}_{2} \mathrm{O}$, HOTs; (e) $\mathrm{Pd}(\mathrm{OAc})_{2}(15 \%),\left[\left(\mathrm{C}_{6} \mathrm{H}_{5}\right)_{2} \mathrm{PCH}_{2}\right]_{2} \mathrm{CH}_{2}(15 \%), \mathrm{Ag}_{2} \mathrm{CO}_{3}, \mathrm{C}_{6} \mathrm{H}_{5} \mathrm{CH}_{3}$. 
<smiles>CC=CC1CCOc2c(OC)ccc(C=O)c21</smiles>

(91)

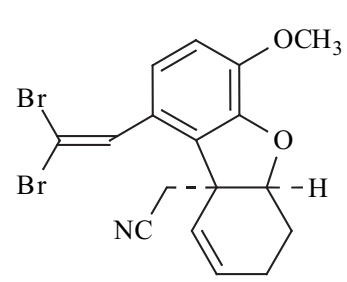

(92)

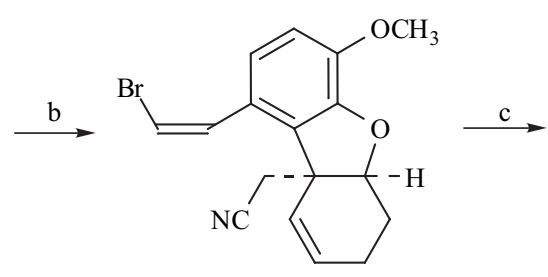

(93)

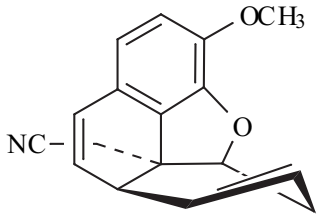

(94)

Fig. (48).

(a) $\mathrm{CBr}_{4},\left(\mathrm{C}_{6} \mathrm{H}_{5}\right)_{3} \mathrm{P}, \mathrm{CH}_{2} \mathrm{Cl}_{2}$; (b) $5 \% \mathrm{Pd}\left[\mathrm{P}\left(\mathrm{C}_{6} \mathrm{H}_{5}\right)_{3}\right]_{4}, n-\mathrm{Bu}_{3} \mathrm{SnH}, \mathrm{C}_{6} \mathrm{H}_{5} \mathrm{CH}_{3}$; (c) $\mathrm{Pd}(\mathrm{OAc})_{2}(15 \%),\left[\left(\mathrm{C}_{6} \mathrm{H}_{5}\right)_{2} \mathrm{PCH}_{2}\right]_{2} \mathrm{CH}_{2}(15 \%), \mathrm{Ag}_{2} \mathrm{CO}_{3}$, $\mathrm{C}_{6} \mathrm{H}_{5} \mathrm{CH}_{3}$.

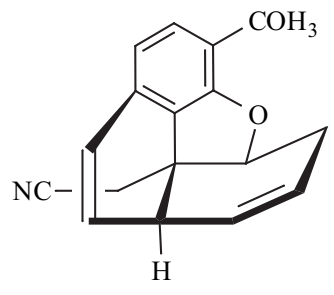

(94)

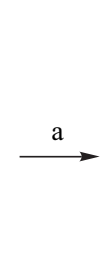

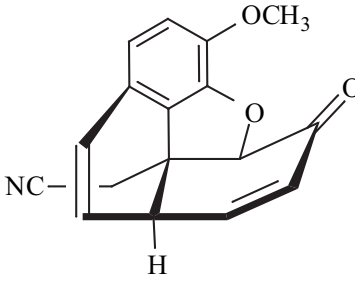

(95)

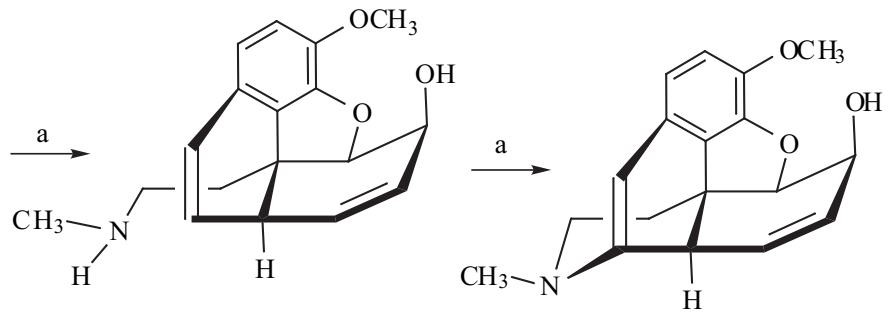

(95)

(2)

Fig. (49).

(a) $\mathrm{SeO}_{2}, 1$,4-dioxane, sand, $75^{\circ} \mathrm{C}$, Dess-Martin periodinane; (b) $\left[\left(\mathrm{CH}_{3}\right)_{2} \mathrm{CHCH}_{2}\right]_{2} \mathrm{AlH} ; \mathrm{CH}_{2} \mathrm{Cl}_{2} / \mathrm{Et}_{2} \mathrm{O}$ followed by $\mathrm{NH}_{4} \mathrm{Br} \mathrm{CH}_{3} \mathrm{NH}_{2}$, followed by $\mathrm{NaBH}_{4}$; (c) LDA/HF with $150 \mathrm{~W}$ tungsten bulb.

The length of the side chain bearing the aldehydic carbon was extended by one carbon and with incorporation of bromine by reaction of 91 with carbon tetrabromide in the presence of triphenylphosphine (in methylene chloride) in $91 \%$ yield to produce 92 . Of the two bromines at the terminus in $\mathbf{9 2}$, that one $(E)$ - to the aromatic ring was removed reductively with tri- $n$-butyltin hydride in the presence of tetrakis-triphenylphosphine palladium and the resulting monobromide (93), formed in $88 \%$ yield, induced to undergo Heck-type cyclization to the cyclohexene 94 (in $65 \%$ yield); Fig. (48).

When the alkene, 94, was oxidized with selenium dioxide and then the Dess-Martin periodinane added to the reaction mixture before workup, the ketone 95 could be isolated in $58 \%$ yield. Reduction of the carbonyl group as well as the nitrile (with the former reducing more easily and thus first) with diisobutylaluminum hydride (DIBAL-H) in methylene chloride-ether followed by addition of ammonium bromide, methylamine and finally sodium borohydride yielded the secondary amine 96; Fig. (49).

The cyclization to codeine (2) was effected by irradiating a basic solution of 96 (lithium diisopropylamide, LDA) in THF with a $150 \mathrm{~W}$ tungsten light bulb.

\section{CONCLUSION}

In the decade during which the syntheses described here were consummated, several key reactions came into prominence. Of major importance were the findings by Parker and Fokas of the "unprecedented" hydroamination reaction, allowing closure of the nitrogen containing ring and, by others, the $\mathrm{Pd}$ catalyzed Heck-type reactions for forging new carbon-carbon bonds. Of course the traditional (and some relatively new or not so traditional modifications) of substitution, addition, elimination, oxidation and reduction reactions were practiced with the skill expected of artisans well versed in their craft. Nonetheless, the unexpected intrusion of a serendipitous observation or finding, for which the well prepared mind had been made ready, is clearly at play here.

Finally, it is clear that another decade will almost certainly find additional and very inventive paths by others who see things in new ways to these edifices of Nature's art.

\section{REFERENCES}

[1] (a) Setürner, F. W. A. Trommsforff's J. Pharm., 1805, 13, 234; (b) ibid, 1806, 14, 47.

[2] Gulland, J. M.; Robinson, R. Mem. Proc. Manchester Lit. Phil. Soc., 1925, 69, 79 .

[3] (a) Gates, M.; Tschudi, G. J. Am. Chem. Soc., 1952, 74, 1109; (b) ibid, 1956, 78, 1380.

[4] See, e.g., Hudlicky, T.; Butora, G.; Fearnley, S.P.; Gum, A. F.; Stabile, M. R. Studies in Natural Products Chemistry, Atta-urRahman, Ed.; Elsevier, Amsterdam, 1996, Vol. 18, pp. 43 -154.

[5] Tius, M. A.; Kerr, M. A. J. Am. Chem. Soc., 1992, 114, 5959.

[6] Luh, T.-Y.; Leung, M.-k.; Wong, K.-T.; Chem. Rev., 2000, 100, 3187

[7] Rapoport, H.; Lovell, C. H.; Tolbert, B. M. J. Am. Chem. Soc., 1951, 73, 5900.

[8] Parker, K. A.; Fokas, D. J. Am. Chem. Soc., 1992, 114, 9688.

[9] (a) Parker, K. A.; Spero, D. M.; Van Epp, J. J. Org. Chem., 1988, 53, 4628; (b) Parker, K.A.; Fokas, D. J. Org. Chem., 1994, 59, 3933.

[10] Robertson, J.; Pillai, J.; Lush, R. Chem. Soc. Rev., 2000, $30,94$.

[11] Weller, D. D.; Rapoport, H. J. Med. Chem., 1976, 19, 1171. 
[12] Hong, C. Y.; Kado, N.; Overman, L. E. J. Am. Chem. Soc., 1993, $115,11028$.

[13] Taber, D. F. J. Org. Chem., 1976, 41, 2649.

[14] White, J. D.; Hrnciar, P.; Stappenbeck, F. J. Org. Chem., 1997, 62, 5250 .

[15] Trauner, D.; Bats, J. W.; Werner, A.; Mulzer, J. J. Org. Chem., 1998, 63, 5908 .
[16] Nagata, J.; Miyazawa, N.; Ogasawara Chem. Comm., 2001, 1094

[17] Nagata, J.; Miyazawa, N.; Ogasawara, K. Synthesis, 2000, 2013.

[18] Taber, D. F.; Neubert, T. D.; Rheingold, A. L. J. Am. Chem. Soc., 2002, 124, 12416.

[19] Trost, B. M.; Tang, W. J. Am. Chem. Soc., 2002, 124, 14542.

[20] Villieras, J.; Rambaud, M.; Graff, M. Syn. Comm., 1986, 16, 149. 